\title{
Bioleaching of Uranium Tailings as Secondary Sources for Rare Earth Elements Production
}

\author{
Nicolas Reynier ${ }^{1}{ }^{(0}$, Roselyne Gagné-Turcotte ${ }^{1}$, Lucie Coudert ${ }^{2, *}{ }^{\circledR}$, Sophie Costis ${ }^{3}\left(\mathbb{O}\right.$, Rory Cameron ${ }^{1}$ \\ and Jean-Francois Blais ${ }^{3}$ (I)
}

1 CanmetMINING, Natural Resources Canada, Ottawa, ON K1A 0E4, Canada; nicolas.reynier@canada.ca (N.R.); roselyne.gagne-turcotte@canada.ca (R.G.-T.); rory.cameron@canada.ca (R.C.)

2 Institut de Recherche en Mines et Environnement, Campus Rouyn-Noranda, Université du Québec en Abitibi-Témiscamingue, Rouyn-Noranda, QC J9X 5E4, Canada

3 Institut National de la Recherche Scientifique, Centre Eau Terre Environnement, Québec, QC G1K 9A9, Canada; sophie.costis@ete.inrs.ca (S.C.); blaisjf@ete.inrs.ca (J.-F.B.)

* Correspondence: lucie.coudert@uqat.ca; Tel.: +1-(819)-762-0971 (ext. 2571)

check for

updates

Citation: Reynier, N.;

Gagné-Turcotte, R.; Coudert, L.;

Costis, S.; Cameron, R.; Blais, J.-F.

Bioleaching of Uranium Tailings as

Secondary Sources for Rare Earth

Elements Production. Minerals 2021,

11, 302. https://doi.org/

$10.3390 / \min 11030302$

Academic Editors: Elizabeth Watkin;

Homayoun Fathollahzadeh and

Melissa Corbett

Received: 28 January 2021

Accepted: 4 March 2021

Published: 16 March 2021

Publisher's Note: MDPI stays neutral with regard to jurisdictional claims in published maps and institutional affiliations.

Copyright: (c) 2021 by the authors and Her Majesty the Queen in Right of Canada. Licensee MDPI, Basel, Switzerland. This article is an open access article distributed under the terms and conditions of the Creative Commons Attribution (CC BY) license (https://creativecommons.org/licenses/by/4.0/).

\begin{abstract}
Tailings from inactive uranium mine sites represent a potential secondary source of rare earth elements (REEs). For this study, two mine tailings (DT and RAT) from restored uranium sites in Ontario, Canada, were used. Bioleaching experiments were conducted with a mix of native sulfurand iron-oxidizing bacteria to test the solubilization of REEs, $U$ and Th at different temperatures (20, 30 and $40^{\circ} \mathrm{C}$ ). The selective recovery of REEs from bioleaching solution was evaluated using different ion exchange resins. The mineralogical characterization revealed that DT tailings were mainly composed of quartz, pyrite, gypsum and silicates, whereas RAT tailings were mainly composed of quartz. The maximum solubilization of heavy and light REEs (HREEs and LREEs, respectively), Th and $\mathrm{U}$ reached $54 \%, 6 \%, 60 \%$ and $51 \%$ for RAT after 35 days at $\mathrm{pH} 2, \mathrm{~T}=30{ }^{\circ} \mathrm{C}$ and pulp density $=10 \%$ $(w / v)$. Higher extraction yields were obtained for DT, with $58 \%$ of HREEs, $14 \%$ of LREEs, $85 \%$ of Th and $89 \%$ of $U$ solubilized under the same conditions. The use of Lewatit TP272 resin for the recovery of Sc $(94 \%)$ and U (99\%) followed by the Lewatit SP112 resin for the recovery of Th (57\%) and REEs (81\% LREEs and 65\% HREEs) seemed a promising method for the co-extraction of the key elements from the bioleaching solution.
\end{abstract}

Keywords: rare earth element; uranium; thorium; bioleaching; mining residue; ion exchange resin

\section{Introduction}

Bioleaching technologies are often considered for processing low-grade and waste material due to their relatively simple operation and low cost compared to conventional processing technologies. In the past decade, there has been significant interest in applying bioleaching microorganisms to extract REEs from different types of metallic and mineralized wastes. In general, there are two different types of biotechnologies applicable to extracting metals from mineralized material: heterotrophic leaching that requires an external carbon source, where microorganisms generate complexing ligands that bind the metals of interest; and autotrophic acidic bioleaching, where solubilization of the metals of interest occur by oxidation of reduced solid phases with ferric ion in combination with acid dissolution. The two pathways use a wide variety of microbial groups (e.g., chemolithoautotrophic bacteria and archaea, chemoorganoheterotrophic bacteria, archaea, and fungi); reviewed in [1,2].

Bioleaching of the individual REE-containing minerals and other solids using both the heterotrophic and autotrophic pathways (and at least one case of co-culturing of both) have been documented in the literature, and reviewed in [1-3]. There is extreme variability in the reported REE leaching efficiencies from mineralized solids, ranging from less than $1 \%$ 
to nearly $100 \%$ [1-3]. The application of phosphate solubilizing microorganisms has been considered for leaching REEs from REE-containing phosphate minerals [4]. In general, heterotrophic bioleaching shows promise; although, it has not been applied on commercial scale [5].

Uranium mine tailings represent a significant potential source of REEs, yet a limited number of studies have reported on the recovery of REEs from $U$ tailings. Uranium and REEs have similar physical characteristics (such as ionic radius), which leads to $U$ incorporation into REE-bearing minerals by lattice substitution [6]. Conversely, significant concentrations of REEs can be found in some U-bearing ore minerals such as uraninite $\left[\mathrm{UO}_{2}\right]$, which ultimately end up in the tailings [7]. The application of bioleaching to $\mathrm{U}$ mine tailings could result in recovering residual $U$ and valuable REEs from material that is considered an environmental liability. Furthermore, bioleaching of $U$ tailings reduces their long-term liabilities as a fraction of the radioactive $U$ is recovered and the potentially acid-producing sulfide minerals are oxidized to material that is more benign.

There are several documented commercial applications of bioleaching to low-grade $U$ ores in different countries; [5] and references therein. Sulfuric acid heap, dump, stope, and in situ leaching of low-grade $\mathrm{U}$ ores have been practiced for decades. It is possible that many of the early operations (pre 1950/60) involved bacterial action but it was generally unknown or undocumented at the time, and engineering design certainly did not promote bacterial action. The benefits of bacterial involvement have increasingly been recognized, studied, and given engineering consideration during process design [5]. During bioleaching of U-bearing ores, minerals and tailings, bacteria do not directly attack the U-bearing minerals, but rather create a physicochemical environment (low $\mathrm{pH}$ and high oxidation-reduction potential) that facilitates dissolution $[5,8-10]$. Their role is to oxidize and dissolve the sulfide minerals and (re)generate Fe(III) ions via bacterial oxidation of $\mathrm{Fe}(\mathrm{II})$. Ferric ion is a powerful oxidant, and readily oxidizes U(IV) (sparingly soluble in an acidic sulfate solution) to $\mathrm{U}(\mathrm{VI})$ (very soluble in an acidic sulfate solution). In addition, the sulfuroxidizing bacteria play a critical role of oxidizing the reduced sulfur species, generating sulfuric acid that maintains a low-pH environment that is necessary to keep ferric ion and the metals of interest in solution.

Acidophilic autotrophic iron- and sulfur-oxidizing Acidithiobacillus and Leptospirillum spp. are generally considered to be the microorganisms primarily responsible for bioleaching of sulfide-containing materials at mesophilic temperatures. Over the past few decades, many additional species, genera, and archaea have been identified to be present and involved in bioleaching systems. The species involved in U bioleaching operations and the mechanisms that affect $U$ mineral solubilization were thoroughly reviewed in [5].

The main objective of the present paper was to evaluate the performance of native bacteria to bioleach REEs, U, Sc, and Th from U mine tailings; followed by selective recovery using ion exchange technology. This paper presents the characterization of tailings from two decommissioned $U$ mines. Bioleaching experiments were performed using shake flasks and stirred tank bioreactors to investigate the bioleaching of REEs, $U$ and Th. Screening of ion exchange resins was done using the pregnant leaching solution (PLS) to identify suitable resins for selective recovery of REEs, Sc, $U$ and Th. Outcomes of this work are the development of innovative technologies for the management of radioactive mine waste and to enhance production of REEs from secondary sources such as $U$ tailings using bioleaching.

\section{Materials and Methods}

\subsection{Mineralogical and Physicochemical Characterization of $U$ Tailings}

A field campaign was conducted in June 2012 at two decommissioned U mines located in the Elliot Lake area (ON, Canada). Various cores and bulk samples, named DT and RAT, were collected from the water-covered Tailings Management Area (TMA) of these sites. Particle size distribution of tailings was determined in duplicate by laser diffraction (Horiba, Partica LA-950V2). Solid samples were partially digested in $\mathrm{HCl}$ using microwave digestion (MarsXpress, CEM) or fully digested by 4-acid digestion using Certified Reference Materials 
(REE-1 and UTS-4) prepared and sold by CCRMP (CanmetMINING, Ottawa, ON, Canada). Aqueous metal determinations were carried out using inductively coupled plasma optic emission spectrometry (ICP-OES, 700 series ICP-OES, Agilent Technologies, Saint-Laurent, QC, Canada) for major elements and inductively coupled plasma mass spectrometry (ICP-MS, X-Series 2, Thermo Scientific, Ottawa, ON, Canada) for trace elements. Sample dilutions were performed with $2 \% \mathrm{HCl}$ (Trace Metal Grade) for ICP-MS and $4 \% \mathrm{HNO}_{3}$ (Trace Metal Grade) for ICP-OES.

X-ray diffraction (XRD) patterns were obtained using a Rigaku D/MAX 2500 rotating anode powder diffractometer with monochromatic $\mathrm{CuK} \alpha$ radiation. Phase identification was achieved using the JADE version 9.3 coupled with the ICSD and ICDD diffraction databases. The samples were micronized and then placed on a zero background plate and disseminated using acetone. The measurement conditions were as follows: $2 \theta$ angular range $=5-70^{\circ}$, step size $=0.020^{\circ}$, scan speed $=1^{\circ} / \mathrm{min}$, voltage $=40 \mathrm{kV}$, amperage $=200 \mathrm{~mA}$. The quantitative mineralogical analysis was performed on "TESCAN Integrated Mineral Analyzer (TIMA)". The combined backscattered (BSE) and energy dispersive (EDS) signals were applied for the phase identification. Accelerating voltage was $25 \mathrm{kV}$. BSE signal was calibrated on Pt Faraday cup, four EDS detectors were calibrated on the Mn standard.

Tessier's sequential extraction protocol [11] was applied in triplicate on both tailings to evaluate the partitioning of metals into five fractions (exchangeable, bound to carbonates, bound to Fe-Mn oxides, bound to organic matter, residual). The extraction steps were conducted in polypropylene centrifuge tubes, with approximately $1 \mathrm{~g}$ of tailings. Between each extraction step, centrifugation was used to separate the solid from the liquid, at 9000 rpm for $30 \mathrm{~min}$ (Labnet, Hermle Z300). A small amount of distilled water was used in between each step to rinse the tailings, and then discarded. Supernatant of each extraction step was collected and analyzed by ICP-OES for Fe and Al, and by ICP-MS for REEs, U, Th and Mn. Table 1 presents the extraction conditions for each sequential extraction step.

Table 1. Tessier's sequential extraction protocol used for DT and RAT tailings.

\begin{tabular}{|c|c|c|c|}
\hline Fraction & Matrix & Extraction Time & Temperature $\left({ }^{\circ} \mathrm{C}\right)$ \\
\hline Exchangeable & $8 \mathrm{~mL}$ of $\mathrm{NaOAc}(1 \mathrm{M}), \mathrm{pH} 7$ & $1 \mathrm{~h}$ & 20 \\
\hline Bound to carbonates & $8 \mathrm{~mL}$ of $\mathrm{NaOAc}(1 \mathrm{M}), \mathrm{pH} 5.0$ & Until equilibrium is reached & 20 \\
\hline Bound to Fe-Mn oxides & $\begin{array}{c}20 \mathrm{~mL} \text { of } \mathrm{Na}_{2} \mathrm{~S}_{2} \mathrm{O}_{4}(0.3 \mathrm{M})+ \\
\text { Na-citrate }(0.175 \mathrm{M})+ \\
\text { H-citrate }(0.025 \mathrm{M})\end{array}$ & Until equilibrium is reached & 96 \\
\hline Bound to organic matter & $\begin{array}{c}3 \mathrm{~mL} \text { of } \mathrm{HNO}_{3}(0.02 \mathrm{M}) \\
+5 \mathrm{~mL} \text { of } \mathrm{H}_{2} \mathrm{O}_{2}(30 \%), \mathrm{pH} 2.0 \\
3 \mathrm{~mL} \text { of } \mathrm{H}_{2} \mathrm{O}_{2}(30 \%), \mathrm{pH} 2.0 \\
5 \mathrm{~mL} \text { of } \mathrm{NH}_{4} \mathrm{OAc}(3.2 \mathrm{M}) \text { in } \mathrm{HNO}_{3}(20 \% \mathrm{v} / \mathrm{v})\end{array}$ & $\begin{array}{c}2 \mathrm{~h} \\
3 \mathrm{~h} \\
30 \mathrm{~min}\end{array}$ & $\begin{array}{l}85 \\
85 \\
20\end{array}$ \\
\hline
\end{tabular}

Residual Microwave aqua regia digestion ( $0.125 \mathrm{~g}$ of tailings)

\subsection{Bioleaching Study}

\subsubsection{Inoculum Enrichment}

To evaluate the bioleaching of $U$ and REEs from mine tailings using native bacteria, a mass of $7 \mathrm{~g}$ of fresh and wet tailings from DT was agitated with $100 \mathrm{~mL}$ of distilled water for 22 weeks (no fresh RAT was available for this study). The batch experiments were done using Erlenmeyer flasks shaken at $200 \mathrm{rpm}$, followed by liquid-solid separation by filtration using Whatman 934AH filters $(0.45 \mu \mathrm{m})$. Metal solubilization, $\mathrm{pH}$, oxidation-reduction potential (ORP) and electrical conductivity (EC) were measured over time to evaluate the growth of native sulfur- and iron-oxidizing bacteria initially present in mine tailings.

\subsubsection{Shake-Flask Experiments}

A mass of $90 \mathrm{~g}$ of each of the two tailings studied was mixed with $200 \mathrm{~mL}$ of sulfur- and iron-oxidizing bacteria inoculum and $400 \mathrm{~mL}$ of McCready growing media made of $0.1 \mathrm{mM}$ 
$\mathrm{K}_{2} \mathrm{HPO}_{4}, 0.5 \mathrm{mM} \mathrm{MgSO} 4 \cdot 7 \mathrm{H}_{2} \mathrm{O}$ and $0.5 \mathrm{mM}\left(\mathrm{NH}_{4}\right)_{2} \mathrm{SO}_{4} \cdot 2 \mathrm{H}_{2} \mathrm{O}$ [12]. The initial $\mathrm{pH}$ was adjusted to $2.0 \pm 0.1$ using dilute sulfuric acid. Shake-flask experiments were conducted for 35 days at three different temperatures $\left(20-30-40{ }^{\circ} \mathrm{C}\right)$ using controlled temperature orbital shakers. Every week, $2 \mathrm{~mL}$ aliquots were taken and then filtered with a Whatman $934 \mathrm{AH}$ filters to stop the process of chemical oxidation of fine particles in the leachate. The liquid samples were stored at $4{ }^{\circ} \mathrm{C}$ and then diluted with $2 \% \mathrm{HCl}$ for ICP-MS analysis.

\subsubsection{Stirred Tank Bioreactor Experiments}

Two $4 \mathrm{~L}$ jacketed stirred tank bioreactors purchased from Wilmad-Labglass (Vineland, NJ, USA) were used in duplicate to scale up shake-flask experiments for both DT and RAT tailings. For each individual experiment, $250 \mathrm{~mL}$ of the culture obtained from the mixture of McCready growing media, sulfur- and iron-oxidizing bacteria inoculum and tailings was added to each $4 \mathrm{~L}$ bioreactor along with $290 \mathrm{~g}$ of tailings. The volume was then brought up to $3 \mathrm{~L}$ with distilled water and adjusted to $\mathrm{pH} 2$ using $10 \% \mathrm{H}_{2} \mathrm{SO}_{4}(v / v)$.

From the results obtained during the orbital shaker tests, a temperature of $30{ }^{\circ} \mathrm{C}$ and a $\mathrm{pH}$ of 2.0 were chosen to operate the experiments. Approximately $2 \mathrm{~mL}$ per stirred tank was sampled four days every week and then filtered using Whatman 934AH filters. Liquid samples were stored at $4{ }^{\circ} \mathrm{C}$ and then diluted with $4 \% \mathrm{HNO}_{3}$. The analysis were carried out in triplicate and analyzed by ICP-OES. The $\mathrm{pH}$ was also adjusted after each sampling to $2.0 \pm 0.1$ using diluted $\mathrm{H}_{2} \mathrm{SO}_{4}$ and the amount of acid used was recorded to evaluate acid consumption over time. Daily monitoring of ORP, EC and dissolved oxygen (DO) was also performed, except on Saturday, Sunday and Monday (due to laboratory access restrictions).

Finally, forced aeration from a compressor was installed to keep the DO level in the bioreactors near saturation point. The flowrate delivered by the air compressor was about $12.5 \mathrm{~L} / \mathrm{min}$. The temperature of the bioreactors was set at $30^{\circ} \mathrm{C}$ and continuous stirring using a radial impeller (which helped to disrupt the flow and lift the particles near the bottom walls of the stirred tanks) was set at around $900 \mathrm{rpm}$. At the end of the study, a partial microwave digestion $(\mathrm{HCl})$ was performed on dry solid samples to validate the obtained results.

\subsection{Ion Exchange Separation}

Twenty different resins were tested to identify the ones that would most likely selectively recover REEs and actinides (e.g., U, Th). Due to the complexity to separate lanthanides from actinides, various strong basic anionic (SBA-Dowex 21K-XLT, Lewatit MP500, Purolite A500, Lewatit K7367, Reillex HQP), weak basic anionic (WBA-Reillex 425, Lewatit A365), strong acid cationic (SAC-Amberlite IR120, Lewatit SP112, Amberlite IRN77), chelating (Rhom \& Haas GT73, Lewatit TP214, Dowex M4195, Lewatit TP260, Lewatit TP207), analytical (Diphonix, UTEVA, RE resin) and impregnated (Lewatit VPOC1026, Lewatit TP272) resins were tested. By combining the bioleaching solution obtained from the stirred tank bioreactors from both RAT and DT, a composite bioleaching solution was obtained. About $1 \mathrm{~g}$ of each resin was added to $100 \mathrm{~mL}$ of this composite bioleaching solution in an Erlenmeyer flask and stirred for $24 \mathrm{~h}$ at $150 \mathrm{rpm}$. The samples were filtered and diluted with $2 \% \mathrm{HCl}$ before ICP-MS analysis. Following exactly the same protocol as before, resin blanks were made by replacing the bioleaching solution with ultrapure water. A method blank was also performed by stirring $100 \mathrm{~mL}$ of the bioleaching solution without resin in an Erlenmeyer flask for $24 \mathrm{~h}$. The screening of the twenty resins tested aimed to identify the most promising to selectively recover REEs and actinides (e.g., Th, U) from the bioleaching solution.

Following the screening step, six resins were evaluated for their capacity to recover metals from the bioleaching solution. For this purpose, a mass of $0.5,1.0,1.5,2.0$, and $2.5 \mathrm{~g}$ of resin was mixed with $100 \mathrm{~mL}$ of solution and stirred for $24 \mathrm{~h}$ at $150 \mathrm{rpm}$. The samples were then filtered and diluted with $2 \% \mathrm{HCl}$ before ICP-MS analysis. 


\section{Results and Discussion}

\subsection{Characterization of the U Mine Tailings}

The chemical composition of the two submerged tailings from $U$ mine sites is presented in Table 2. These results are consistent with the main minerals identified in the different mine tailings through XRD analysis presented in Figure 1. Indeed, both samples are mainly composed of quartz, illite, gypsum, pyrite, microcline, calcite and muscovite.

Table 2. Element concentrations measured in tailings from the $U$ mine sites.

\begin{tabular}{|c|c|c|}
\hline Elements Concentration & RAT & DT \\
\hline \multicolumn{3}{|l|}{ Major elements (\%) } \\
\hline $\mathrm{Mg}$ & 0.34 & 0.06 \\
\hline $\mathrm{Al}$ & 1.31 & 1.07 \\
\hline K & 0.61 & 1.07 \\
\hline $\mathrm{Ca}$ & 0.13 & 0.09 \\
\hline $\mathrm{Ti}$ & 0.11 & 0.07 \\
\hline $\mathrm{Fe}$ & 2.2 & 0.89 \\
\hline $\mathrm{Si}$ & 31.8 & 42.2 \\
\hline$S$ & 0.26 & 0.18 \\
\hline $\mathrm{C}$ & 6.0 & 4.7 \\
\hline \multicolumn{3}{|l|}{ Minor elements (mg/kg) } \\
\hline $\mathrm{Mn}$ & 208 & 67.9 \\
\hline $\mathrm{Ni}$ & 263 & 7.25 \\
\hline Th & 146 & 204 \\
\hline $\mathrm{U}$ & 378 & 67.1 \\
\hline Sc & 0.9 & 0.0 \\
\hline $\mathrm{Y}$ & 28.4 & 31.7 \\
\hline $\mathrm{La}$ & 346 & 456 \\
\hline $\mathrm{Ce}$ & 619 & 827 \\
\hline $\operatorname{Pr}$ & 62.7 & 84.3 \\
\hline $\mathrm{Nd}$ & 204 & 270 \\
\hline $\mathrm{Sm}$ & 28.1 & 42.1 \\
\hline $\mathrm{Eu}$ & 1.5 & 1.2 \\
\hline Gd & 22 & 28.4 \\
\hline $\mathrm{Tb}$ & 2.5 & 2.5 \\
\hline Dy & 7.7 & 9.3 \\
\hline Ho & 1.3 & 1.3 \\
\hline Er & 4.0 & 3.6 \\
\hline $\mathrm{Tm}$ & 0.3 & 0.4 \\
\hline $\mathrm{Yb}$ & 1.9 & 1.7 \\
\hline $\mathrm{Lu}$ & 0.2 & 0.0 \\
\hline LREEs & 1262 & 1681 \\
\hline HREEs & 68.3 & 78.9 \\
\hline TREEs & 1330 & 1760 \\
\hline
\end{tabular}

Total REEs (TREEs) content measured in tailings were estimated at 1330 and 1760 $\mathrm{mg} / \mathrm{kg}$ for the RAT and DT tailings, respectively. Much lower HREEs concentrations (68.3 and $78.9 \mathrm{mg} / \mathrm{kg}$ for the RAT and DT tailings, respectively) were recorded relative to LREEs (1262 and $1681 \mathrm{mg} / \mathrm{kg}$ for the RAT and DT tailings, respectively). Indeed, LREEs account for $85-97 \%$ of the TREEs measured in the different $U$ mine tailings under study. Similar observations were made from Australian mine tailings, showing that $97 \%$ of the TREEs $(4719 \mathrm{mg} / \mathrm{kg}$ ) were LREEs, with Ce being the most abundant REE (2230 $\mathrm{mg} / \mathrm{kg})$ [13]. Tailings from the DT site have the highest levels of Th $(204 \mathrm{mg} / \mathrm{kg})$, while tailings from the RAT site contain the highest levels of $\mathrm{U}(378 \mathrm{mg} / \mathrm{kg})$. In comparison, tailings from a rehabilitated former U mine site (Australia) contained $133-257 \mathrm{mg} / \mathrm{kg}$ of Th and 7.2-42.7 mg/kg of U [14]. During the search for U- and Th-bearing phases by XRD, several REE-bearing carbonates were observed for RAT but not identified due to pick overlapping. This tailing was selected for TESCAN Integrated Mineral Analyzer 
(TIMA) analysis and results are presented in Table 3. The content of pyrite was estimated at $5.50 \%$, while the contents of monazite and uraninite were estimated at $0.54 \%$ and $0.20 \%$, respectively. Allanite-(Ce) and bastnasite were also identified at lower concentration $(0.08 \%$ and $0.02 \%$, respectively).

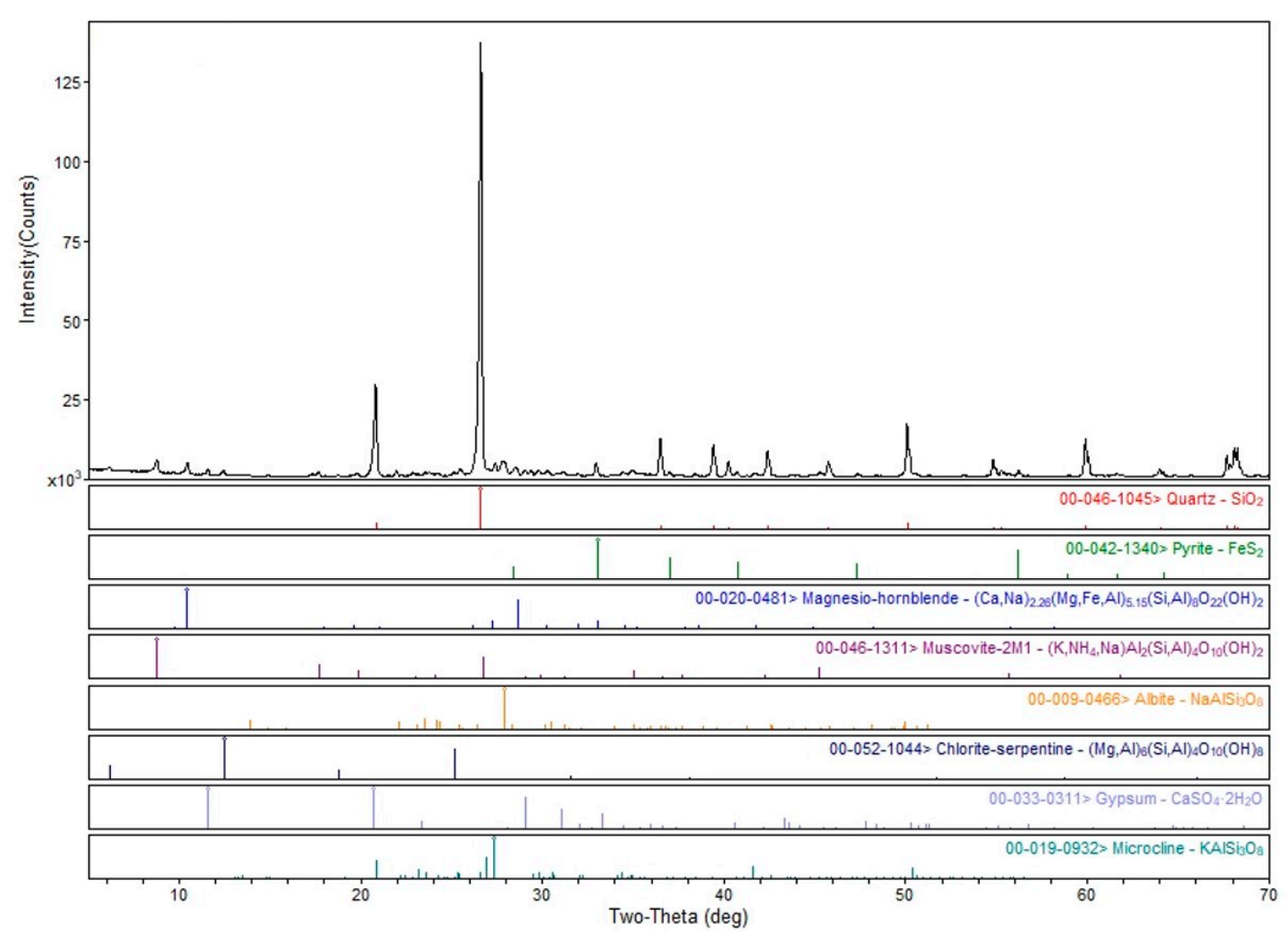

(a)

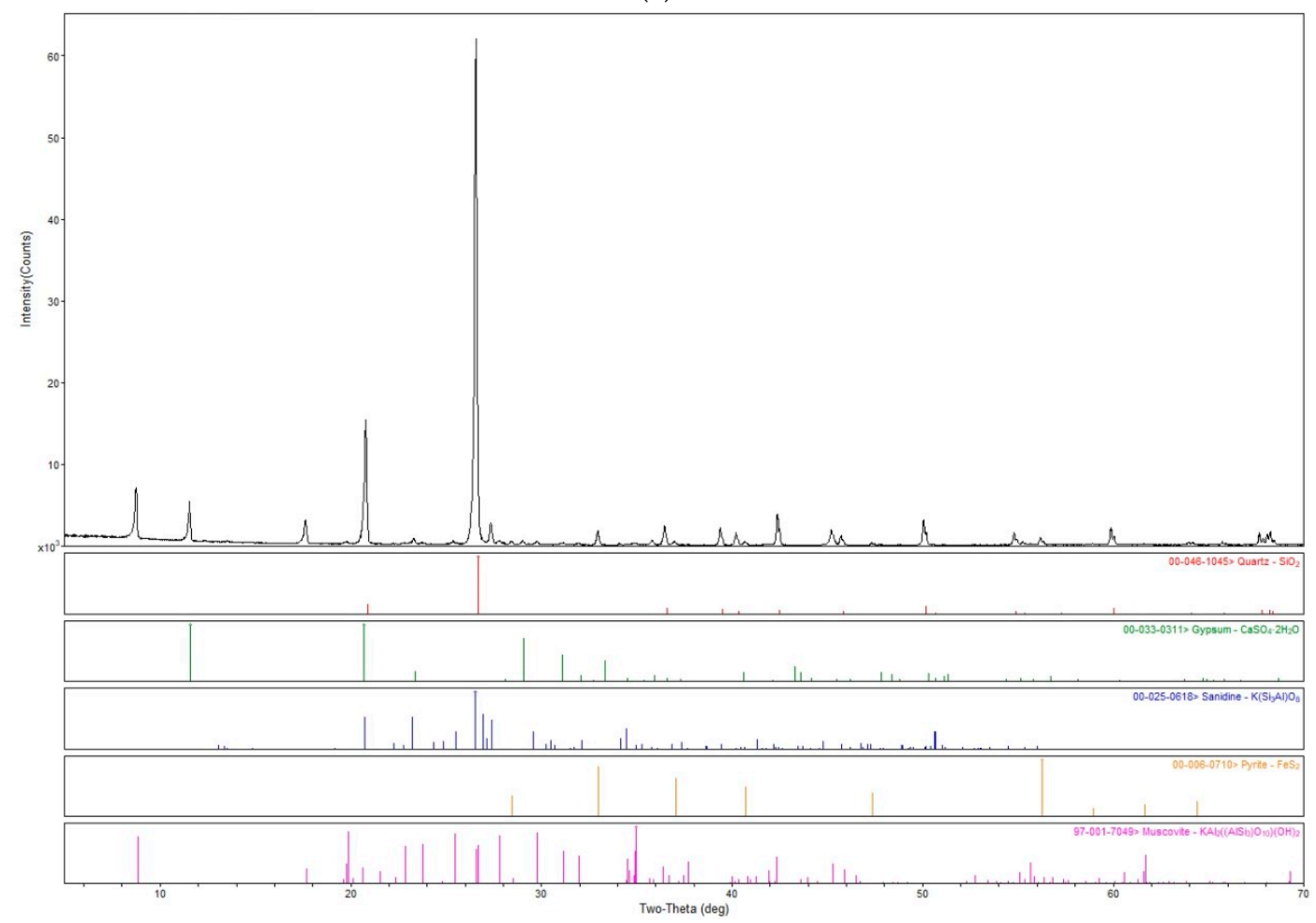

(b)

Figure 1. XRD patterns of RAT (a) and DT (b) tailings. 
Table 3. Mineral percentage determination obtained by TESCAN Integrated Mineral Analyzer (TIMA) analysis.

\begin{tabular}{cccc}
\hline Mineral & Weight (\%) & Mineral & Weight (\%) \\
\hline Quartz & 64.22 & Ferro-Actinolite & 0.09 \\
Muscovite & 13.43 & Allanite-(Ce) & 0.08 \\
Pyrite & 5.50 & Ilmenite & 0.08 \\
Orthoclase & 3.42 & Hornblende & 0.08 \\
Anorthite & 2.82 & Bannisterite & 0.06 \\
Albite & 1.62 & Apatite & 0.06 \\
Calcite & 1.16 & Kaolinite & 0.05 \\
Kaersutite & 1.09 & Zircon & 0.04 \\
Hematite/Magnetite & 1.06 & Jacobsite & 0.03 \\
Magnesiogedrite & 0.69 & Diopside & 0.02 \\
Plagioclase & 0.55 & Bastnasite & 0.02 \\
Monazite & 0.54 & Titanite & 0.02 \\
Actinolite & 0.50 & Chalcopyrite & 0.02 \\
Biotite & Dolomite & 0.01 \\
Ferrocarpholite & 0.38 & Schorl & 0.01 \\
Columbite & 0.29 & Stibnite & 0.01 \\
Anhydrite & 0.28 & Kyanite & 0.01 \\
Rutile & 0.23 & Celestite & 0.01 \\
Pyrrhotite & 0.23 & Enstatite-(Fe) & 0.01 \\
Uraninite & 0.22 & Ankerite + clay & 0.01 \\
Ferrosaponite & 0.20 & Covellite & 0.01 \\
Garnet-Pyrope & 0.18 & Pentlandite & 0.01 \\
Ankerite & 0.17 & Sphalerite & 0.01 \\
Ankerite + clay (Fe) & 0.12 & Nepheline & 0.01 \\
Baryte & 0.12 & Other & 0.03 \\
Wollastonite & 0.10 & Total & 100 \\
\hline & 0.10 & &
\end{tabular}

Figure 2 shows the particle size distribution of DT and RAT (in duplicate) determined using a laser diffractometer. The particles of the RAT have a larger diameter than those of DT. In fact, most of the particles have a diameter of $400 \mu \mathrm{m}$ for the RAT, while the particles of DT mainly have a diameter of $100 \mu \mathrm{m}$.

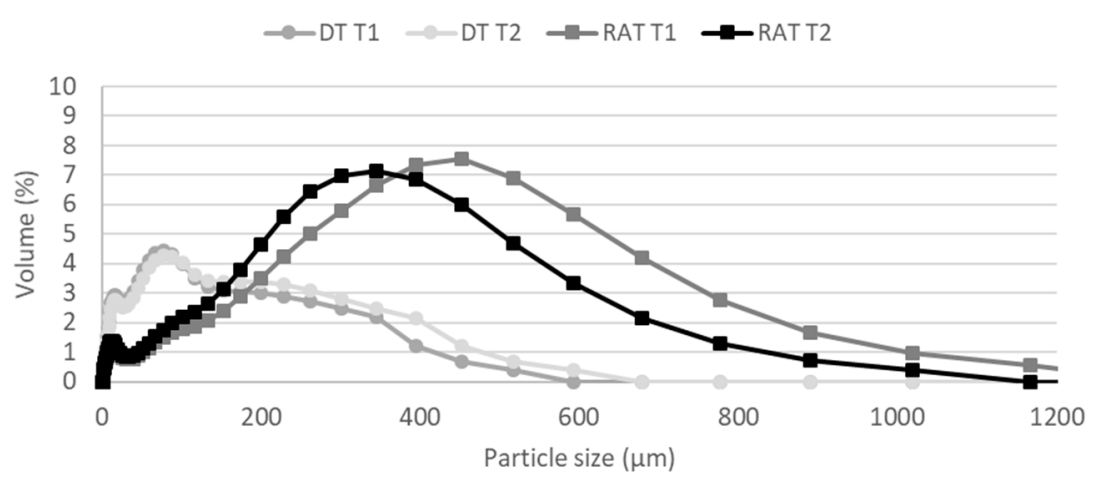

Figure 2. Particle size distribution of DT and RAT (in duplicate) determined by a laser diffractometer.

The partitioning (mean values) of the main elements of interest (e.g., Fe, Mn, REEs, U, Th), determined in triplicate using the Tessier's five-step sequential extraction, is shown in Table 4 for RAT and DT. In the RAT tailings, $U$ is mainly found in the weak acid soluble fraction $(87.8 \%)$ while $\mathrm{U}$ is split between the exchangeable $(17.7 \%)$, weak acid $(22.5 \%)$, the Fe-Mn oxide (19.7\%), and the residual fraction (38.7\%) in the DT tailings. These results indicate that $\mathrm{U}$ from RAT, probably present as uranium carbonate complexes, is expected to dissolve easily through bioleaching, while U from DT tailing is expected to be more difficult to extract, as more than $38.7 \%$ is present in the residual fraction (e.g., silicates), 
that is known to be more difficult to solubilize by diluted inorganic acids [15]. In both tailings, a similar partition of Fe and LREEs as well as Th and HREEs is observed. Indeed, $\mathrm{Fe}$ and LREEs seem to be mainly present in the residual fraction $(86.0-89.55 \%$ for $\mathrm{Fe}$ and $56.9-96.4 \%$ for LREEs), while Th and most of HREEs were split between the weak acid, the Fe-Mn oxide, and the residual fraction. Considering this partitioning, a better bioleaching of HREEs hosted in the minerals associated with Fe- and S-bearing minerals (pyrite) is expected.

\subsection{Inoculum Enrichment}

The bioleaching of $U$ and REEs from mine residues using native bacteria was investigated by mixing fresh tailings from DT for 22 weeks in $100 \mathrm{~mL}$ of distilled water. The evolution of $\mathrm{pH}, \mathrm{ORP}, \mathrm{EC}$ as well as the concentrations of $\mathrm{Fe}, \mathrm{Mn}, \mathrm{U}$, Th, LREEs and HREEs (Figure 3) was monitored once a week.

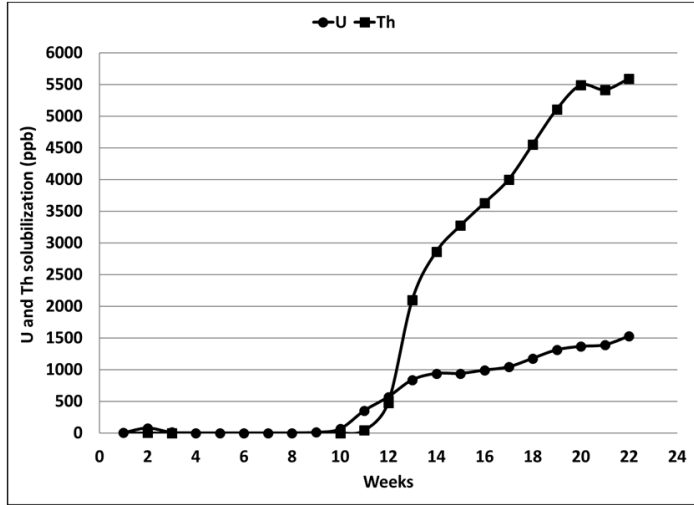

(a)

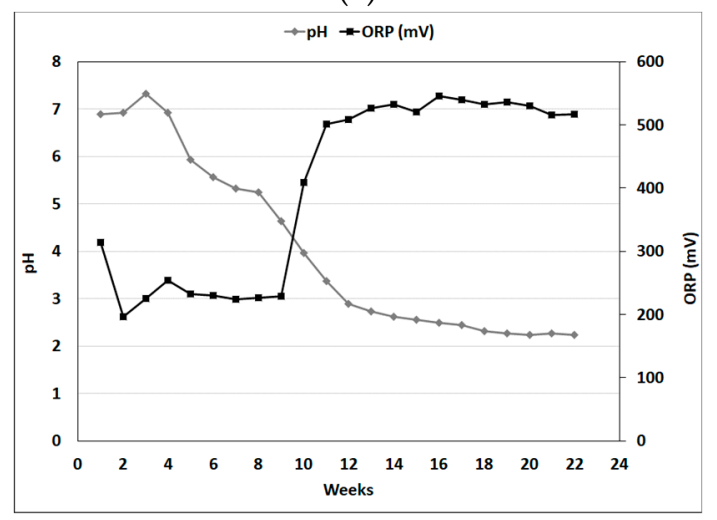

(c)

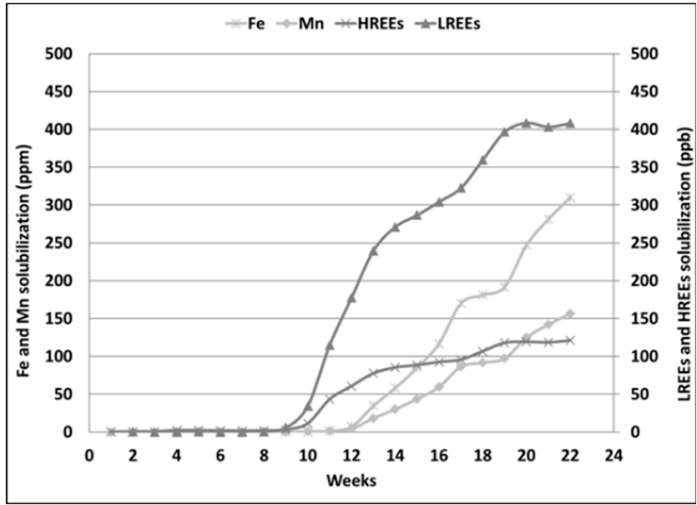

(b)

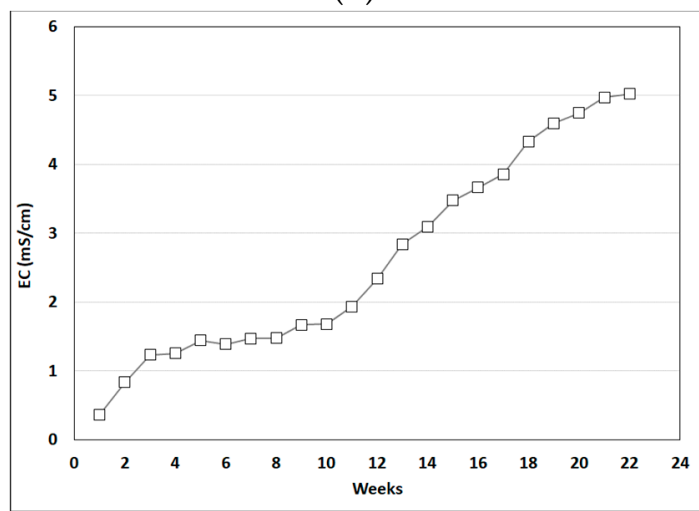

(d)

Figure 3. Metal solubilization from DT tailings during the 22 weeks in distilled water. (a) $\mathrm{U}$ and Th (in $\mu \mathrm{g} / \mathrm{L}$ ), (b) Fe and Mn (in mg/L), LREEs and HREEs (in $\mu \mathrm{g} / \mathrm{L}$ ), (c) pH and ORP (in $\mathrm{mV}$ ), and (d) EC (in mS/cm).

For the DT tailings, the initial $\mathrm{pH}$ decreases from 7 (in the 5th week) to 4 (in the 10th week). The final $\mathrm{pH}$, near $\mathrm{pH} 2$, was reached in the 20th week. The acidification may be due to pyrite oxidation and/or the development of sulfur- and iron-oxidizing bacteria. For the ORP, the initial value around $250 \mathrm{mV}$ increased to $500 \mathrm{mV}$ between weeks 9 and 11 , and then remained constant. This ORP evolution indicated that the oxidation of $\mathrm{Fe}^{2+}$ to $\mathrm{Fe}^{3+}$ through the activity of native iron-oxidizing bacteria occurred in the DT tailings. A slight increase for the EC (from 0.36 to $5.0 \mathrm{mS} / \mathrm{cm}$ ) of the DT sample was observed, indicating that some elements were solubilized. 
Table 4. Mean extraction results (\% by weight) of sequential extraction analysis of tailings from RAT and DT $(\mathrm{n}=3)$.

\begin{tabular}{|c|c|c|c|c|c|c|c|c|c|c|}
\hline & \multicolumn{5}{|c|}{ RAT } & \multicolumn{5}{|c|}{ DT } \\
\hline & Exchangeable Ions & $\begin{array}{l}\text { Weak Acid } \\
\text { Soluble }\end{array}$ & Fe-Mn Oxide & $\begin{array}{c}\text { Bound to } \\
\text { Organic Matter }\end{array}$ & Residual & Exchangeable Ions & $\begin{array}{l}\text { Weak Acid } \\
\text { Soluble }\end{array}$ & Fe-Mn Oxide & $\begin{array}{c}\text { Bound to } \\
\text { Organic Matter }\end{array}$ & Residua \\
\hline $\mathrm{Fe}$ & 0.0 & 2.2 & 4.6 & 3.7 & 89.5 & 0.0 & 1.8 & 12.3 & 0.0 & 86.0 \\
\hline $\mathrm{Mn}$ & 6.3 & 12.9 & 11.9 & 4.4 & 64.5 & 25.7 & 27.4 & 27.2 & 0.0 & 19.7 \\
\hline $\mathrm{U}$ & 5.0 & 87.8 & 0.0 & 1.7 & 5.5 & 17.1 & 22.5 & 19.7 & 2.0 & 38.7 \\
\hline $\mathrm{Th}$ & 0.0 & 33.5 & 26.6 & 0.0 & 39.9 & 0.0 & 13.5 & 71.7 & 0.0 & 14.8 \\
\hline $\mathrm{Ce}$ & 0.1 & 2.3 & 1.1 & 0.0 & 96.4 & 0.1 & 2.2 & 7.8 & 0.0 & 89.9 \\
\hline $\mathrm{Sm}$ & 0.3 & 7.1 & 3.1 & 0.0 & 89.5 & 0.4 & 7.6 & 23.0 & 0.0 & 69.0 \\
\hline $\mathrm{Eu}$ & 0.4 & 10.4 & 4.4 & 0.1 & 84.7 & 0.6 & 11.6 & 30.9 & 0.0 & 56.9 \\
\hline $\mathrm{Gd}$ & 0.6 & 13.3 & 5.3 & 0.0 & 80.9 & 0.9 & 14.5 & 32.7 & 0.0 & 51.8 \\
\hline $\mathrm{Tb}$ & 0.8 & 24.5 & 9.7 & 0.0 & 65.4 & 1.0 & 21.5 & 44.6 & 0.0 & 32.9 \\
\hline Dy & 0.9 & 33.6 & 12.4 & 0.0 & 53.0 & 1.2 & 26.9 & 48.3 & 0.0 & 23.6 \\
\hline Ho & 1.0 & 38.5 & 13.7 & 0.0 & 46.8 & 1.3 & 30.7 & 48.2 & 0.0 & 19.8 \\
\hline Er & 0.7 & 35.5 & 12.4 & 15.1 & 36.2 & 0.9 & 23.7 & 34.0 & 32.8 & 8.7 \\
\hline $\mathrm{Tm}$ & 0.5 & 42.8 & 15.2 & 0.0 & 41.5 & 0.9 & 34.2 & 48.5 & 0.0 & 16.4 \\
\hline $\mathrm{Yb}$ & 0.4 & 38.3 & 15.1 & 0.0 & 46.2 & 0.7 & 33.2 & 49.4 & 0.0 & 16.6 \\
\hline
\end{tabular}


Figure 3 presents the evolution of the solubilization of $\mathrm{Fe}, \mathrm{Mn}, \mathrm{U}$, Th as well as LREEs and HREEs from DT tailings during the 22 weeks of inoculum experiments. Based on these results, an important metal solubilization trend was observed. Indeed, the LREEs concentration increased to achieve $400 \mu \mathrm{g} / \mathrm{L}$, while $\mathrm{U}$ and Th concentrations increased up to $1.5 \mathrm{mg} / \mathrm{L}$ and $5.5 \mathrm{mg} / \mathrm{L}$, respectively. However, the solubilization of REEs, U and Th only started during the 10th week, when the $\mathrm{pH}$ decreased to 4 and when ORP values and solubilized Fe contents increased. Previous studies showed that the solubilization of Th and $\mathrm{U}$ can be explained by the presence of $\mathrm{Fe}^{3+}$, an oxidizing agent favoring the oxidation of insoluble U(IV) to soluble U(VI), and the acidic conditions [8-10]. These results highlighted the partial dissolution of the minerals containing actinides (e.g., uraninite) and REEs (e.g., monazite, bastnasite, allanite-(Ce)). Similar observations related to the behavior of REEs were made during bioleaching experiments conducted on monazite concentrate using autotrophic microorganisms (Acidithiobacillus ferrooxidans) [16]. Indeed, the authors observed that the dissolution rate of REEs-bearing minerals increased as the $\mathrm{pH}$ of the bioleaching solution decreased.

\subsection{Shake-Flask Experiments}

After 22 weeks of inoculation, bioleaching experiments were conducted in shakeflasks at different temperatures $\left(20-30-40{ }^{\circ} \mathrm{C}\right)$ in the presence of the native sulfur- and iron-oxidizing bacteria. During the bioleaching experiment, the $\mathrm{pH}$ remained stable around 2.0 for both DT and RAT tailings. The ORP was measured weekly and reached $565 \mathrm{mV}$ at the end of the experiment at $30{ }^{\circ} \mathrm{C}$ for both DT and RAT tailings, indicating that the conditions were favorable for the oxidation of ferrous to ferric ions by iron-oxidizing bacteria. Tables 5 and 6 present the metal solubilization observed during the 8 weeks of experiments at different temperatures $\left(20-30-40^{\circ} \mathrm{C}\right)$ from RAT and DT tailings, respectively. For each table, the duplicate performed at $20^{\circ} \mathrm{C}$ indicated, except for U (1-16\%), a low variability $(1-7 \%)$ in metal solubilization for these experiments conducted under similar conditions and therefore, an acceptable reproducibility of the results.

Table 5. Metal solubilization (\%) from RAT tailings during the 8 weeks of experiments and ORP value (mV).

\begin{tabular}{|c|c|c|c|c|c|c|}
\hline Temperature $\left({ }^{\circ} \mathrm{C}\right)$ & Week & Th & $\mathbf{U}$ & Mean LREEs & Mean HREEs & ORP \\
\hline 20 & 1 & 2 & 19 & 1 & 9 & 481 \\
\hline 20 & 2 & 9 & 78 & 2 & 20 & 525 \\
\hline 20 & 3 & 21 & 74 & 3 & 24 & 540 \\
\hline 20 & 4 & 23 & 75 & 3 & 23 & 505 \\
\hline 20 & 8 & 25 & 73 & 3 & 21 & 509 \\
\hline 20-Duplicate & 1 & 3 & 20 & 1 & 9 & 542 \\
\hline 20-Duplicate & 2 & 2 & 62 & 2 & 14 & 555 \\
\hline 20-Duplicate & 3 & 14 & 69 & 2 & 18 & 568 \\
\hline 20-Duplicate & 4 & 23 & 87 & 3 & 24 & 555 \\
\hline 20-Duplicate & 8 & 26 & 69 & 3 & 21 & 528 \\
\hline 30 & 1 & 4 & 18 & 1 & 11 & 429 \\
\hline 30 & 2 & 16 & 66 & 2 & 18 & 519 \\
\hline 30 & 3 & 23 & 66 & 3 & 21 & 556 \\
\hline 30 & 4 & 26 & 69 & 3 & 23 & 565 \\
\hline 30 & 8 & 42 & 85 & 4 & 35 & 586 \\
\hline 40 & 1 & 4 & 18 & 1 & 10 & 413 \\
\hline 40 & 2 & 21 & 68 & 3 & 22 & 523 \\
\hline 40 & 3 & 18 & 62 & 2 & 20 & 504 \\
\hline 40 & 4 & 26 & 68 & 3 & 25 & 513 \\
\hline 40 & 8 & 35 & 69 & 4 & 33 & 529 \\
\hline
\end{tabular}


Table 6. Metals solubilization (\%) from DT tailings during the 8 weeks of experiments and ORP value (mV).

\begin{tabular}{|c|c|c|c|c|c|c|}
\hline Temperature $\left({ }^{\circ} \mathrm{C}\right)$ & Week & Th & $\mathbf{U}$ & Mean LREEs & Mean HREEs & ORP \\
\hline 20 & 1 & 3 & 10 & 1 & 16 & 432 \\
\hline 20 & 2 & 28 & 26 & 3 & 41 & 435 \\
\hline 20 & 3 & 64 & 34 & 6 & 57 & 500 \\
\hline 20 & 4 & 90 & 45 & 7 & 68 & 505 \\
\hline 20 & 8 & 81 & 46 & 8 & 67 & 537 \\
\hline 20-Duplicate & 1 & 8 & 15 & 2 & 21 & 549 \\
\hline 20-Duplicate & 2 & 39 & 30 & 4 & 45 & 569 \\
\hline 20-Duplicate & 3 & 74 & 38 & 7 & 61 & 583 \\
\hline 20-Duplicate & 4 & 89 & 46 & 7 & 64 & 553 \\
\hline 20-Duplicate & 8 & 81 & 41 & 7 & 62 & 577 \\
\hline 30 & 1 & 7 & 13 & 2 & 21 & 473 \\
\hline 30 & 2 & 54 & 32 & 5 & 53 & 544 \\
\hline 30 & 3 & 74 & 39 & 7 & 62 & 543 \\
\hline 30 & 4 & 76 & 41 & 6 & 56 & 565 \\
\hline 30 & 8 & 74 & 50 & 7 & 71 & 596 \\
\hline 40 & 1 & 2 & 10 & 1 & 12 & 500 \\
\hline 40 & 2 & 58 & 34 & 6 & 53 & 537 \\
\hline 40 & 3 & 68 & 39 & 6 & 54 & 521 \\
\hline 40 & 4 & 68 & 42 & 5 & 49 & 523 \\
\hline 40 & 8 & 65 & 36 & 7 & 70 & 590 \\
\hline
\end{tabular}

A high solubilization of U (68-87\%) was observed for RAT tailings after only two weeks of experiment, while the solubilization of Th and HREEs remained quite low (9-23\% for Th and $14-24 \%$ for HREEs), even at the end of the experiment (Table 5). These variable efficiencies might be explained by the different partitioning of $U$ (mainly found in the weak acid soluble fraction) relative to Th and HREEs (associated with the weak acid soluble, the Fe-Mn oxides and the residual fractions) previously observed in RAT tailings. Indeed, a better solubilization of the elements (e.g., $\mathrm{U}$ ) associated with exchangeable and weak acid soluble fractions was expected relative to those partially (e.g., Th and HREEs) or mainly (e.g., LREEs) associated with more refractory fractions (e.g., residual). For the DT tailings, the solubilization of $U$, Th and HREEs was slower relative to RAT tailings ( 3 weeks vs. 2 weeks), but satisfactory solubilization was observed for both Th (up to 90\%) and HREEs (up to $68 \%$ ) starting at the third week, while moderate solubilization was achieved (41-46\%) (Table 6).

The higher solubilization of Th and HREEs observed after 4 weeks for DT tailings (68-90\% for Th and $49-68 \%$ for HREEs) relative to RAT tailings (23-26\% for Th and $23-25 \%$ for HREEs), might be due to the smallest particles size $\left(\mathrm{d}_{80}=118 \mu \mathrm{m}\right.$ and $443 \mu \mathrm{m}$ for DT and RAT, respectively) as well as the higher proportion of both Th and HREEs associated to the Fe-Mn oxides and the lower proportion associated to the residual fraction in DT tailings compared to RAT tailings. A slight decrease in HREEs solubilization might be noticed in DT tailings after three weeks of experiments under certain conditions (tests at 30 and $40{ }^{\circ} \mathrm{C}$ ). This could be explained by a phenomenon of surface passivation of the residue particles or a drop in bacterial activity attributable to a nutrient deficiency. It is also possible that the non-leached HREEs are not solubilized because they are finely disseminated in the tailings. A very low solubilization of LREEs $(<7 \%)$ was observed for both RAT and DT tailings, this can be explained by the fact that the LREEs were mainly associated with the residual fraction (56.9-96.4\%), that is more difficult to solubilize under acidic conditions encountered in bioleaching experiments ( $\mathrm{pH}$ near 2). As expected from the different partitioning of HREEs and LREEs in both RAT and DT tailings, the solubilization of HREEs (associated with sulfur minerals) is more efficient than for LREEs (associated with monazite). 
The experiments were pursued over four other weeks and the $\mathrm{pH}$ was adjusted weekly at a value of 2 . At week 8 , the best increases of the ORP values were observed at a temperature of $30{ }^{\circ} \mathrm{C}$ and reached $596 \mathrm{mV}$ for DT tailings, and $586 \mathrm{mV}$ for RAT tailings. A metal solubilization of $74 \%$ for Th, $50 \%$ for U, $7 \%$ for LREEs, and $71 \%$ for HREEs was obtained for DT. For RAT, the metal solubilization at week 8 reached $42 \%$ for $\mathrm{U}, 85 \%$ for Th, $4 \%$ for LREEs, and 35\% for HREEs. Therefore, the subsequent bioleaching experiments conducted in stirred tank reactors were performed at $30^{\circ} \mathrm{C}$ to favor the growth of sulfur- and iron-oxidizing bacteria and oxidative conditions required to enhance the solubilization of $\mathrm{U}(\mathrm{VI})$. The bioleaching solution produced during the shake-flask experiment was collected for recovery studies.

\subsection{Stirred Tank Bioreactor Experiments}

Figure 4 shows the evolution of the electrical conductivity (EC) and the oxidationreduction potential (ORP) measured during the 30-day experiments conducted in duplicate (stirred tank 1 and 2) for RAT and DT tailings, while the evolution of HREEs, LREEs, Th and $U$ contents is presented in Supplementary Figures S1 and S2. An important increase in the ORP was noticeable during the first six days (RAT) or five days (DT) of the experiments for both tailings (up to $531 \mathrm{mV}$ for RAT and $456 \mathrm{mV}$ for DT). However, starting in day 7 (RAT) or day 6 (DT), the ORP stabilized into an asymptote, slightly oscillating around these values, indicating that oxidizing conditions were well-established, favoring the oxidation of $\mathrm{Fe}(\mathrm{II})$ to $\mathrm{Fe}(\mathrm{III})$ and $\mathrm{U}(\mathrm{IV})$ to $\mathrm{U}(\mathrm{VI})$. For dissolved oxygen (DO) content, the values were stable for the entire duration of the experiment and oscillated around $7.2 \mathrm{mg} / \mathrm{L}$ and 8.8 $\mathrm{mg} / \mathrm{L}$ for RAT and DT, respectively. These values were close to the saturation point of oxygen in water at a temperature of $30^{\circ} \mathrm{C}$. For the first experiment performed on RAT tailings, a forced aeration supply was not initially planned, but the observation of extremely low levels of DO during the second day of the study $(0.07 \mathrm{mg} / \mathrm{L}$ and $0.02 \mathrm{mg} / \mathrm{L}$ for the stirred tank 1 and 2, respectively) highlighted the need for an exterior source of oxygen. To avoid a similar scenario, the air compressor was implemented at the beginning of the experiment for DT.

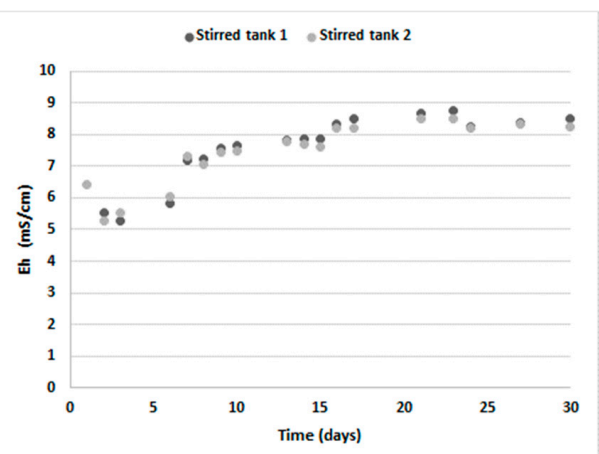

(a)

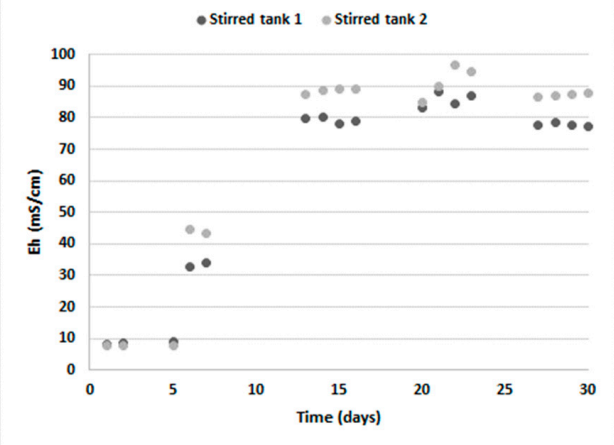

(c)

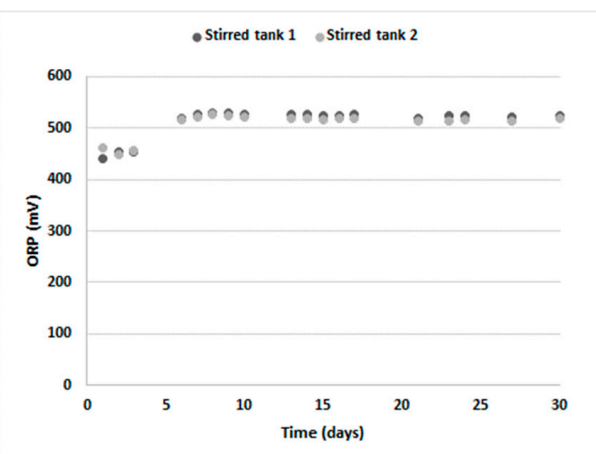

(b)

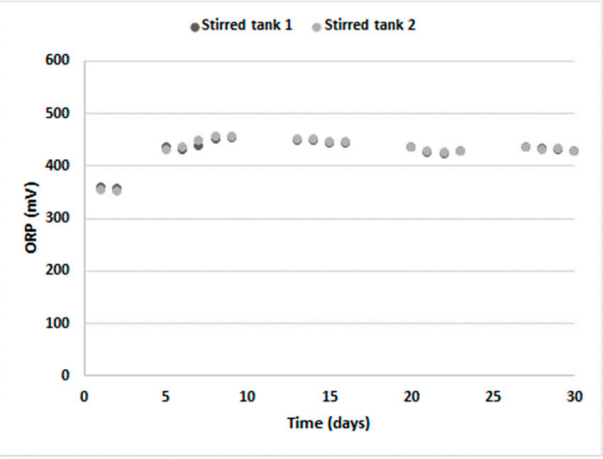

(d)

Figure 4. EC (a,c) and ORP (b,d) evolution for RAT $(\mathbf{a}, \mathbf{b})$ and DT (c,d) tailings. 
Table 7 compares the results obtained by the bioleaching process in orbital shaker (OS) and in stirred tank bioreactors (STB). For RAT tailings, the extraction efficiencies of Th and REEs (especially HREEs) observed for STB were higher than that obtained on a smaller scale (OS). However, U extraction was slightly lower than the one measured in OS. On the other hand, bioleaching of DT tailings shows well-defined extraction kinetics for $U$, Th and REEs in addition to giving better extraction yields than the ones previously obtained in OS $(+8 \%$ for Th, $+46 \%$ for $\mathrm{U},+8 \%$ for LREEs and $+1 \%$ for HREEs). The better results obtained during the bioreactor tests than during STB might be explained by a better oxygen transfer in the bioreactor with a direct and continuous supply of air and a vigorous agitation of the pulp using a mechanical stirrer equipped with a radial impeller (which helped to disrupt the flow and lift the particles near the bottom walls of the stirred tanks), clearly more efficient than in the flasks. A lower HREEs removal efficiency can be noted for RAT tailings after three weeks of experiments, this can be due to slight variations in sample collection over time and analytical errors ( $\pm 3 \%$ mean variation for HREEs analysis observed in duplicates for RAT), slightly impacting the calculations of HREEs removals.

Table 7. Comparison of the metal solubilization obtained during the experiment in orbital shaker (OS-left column) and stirred tank bioreactor (STB-right column) at $30{ }^{\circ} \mathrm{C}$ for RAT and DT tailings.

\begin{tabular}{|c|c|c|c|c|c|c|c|c|}
\hline \multirow[t]{2}{*}{ Week } & \multicolumn{2}{|c|}{ Th (\%) } & \multicolumn{2}{|c|}{ U (\%) } & \multicolumn{2}{|c|}{ LREEs (\%) } & \multicolumn{2}{|c|}{ HREEs (\%) } \\
\hline & OS & STB & OS & STB & OS & STB & OS & STB \\
\hline \multicolumn{9}{|l|}{ RAT } \\
\hline 1 & 4.2 & 57 & 18 & 48 & 1.3 & 4.6 & 11 & 50 \\
\hline 2 & 16 & 59 & 66 & 49 & 2.0 & 5.0 & 18 & 51 \\
\hline 3 & 23 & 61 & 66 & 50 & 2.5 & 5.2 & 21 & 45 \\
\hline 4 & 26 & 60 & 69 & 51 & 2.5 & 5.8 & 23 & 54 \\
\hline \multicolumn{9}{|l|}{ DT } \\
\hline 1 & 6.7 & 35 & 13 & 53 & 1.6 & 5.5 & 21 & 35 \\
\hline 2 & 54 & 72 & 32 & 75 & 5.4 & 12 & 53 & 48 \\
\hline 3 & 74 & 81 & 39 & 87 & 6.7 & 14 & 62 & 55 \\
\hline 4 & 76 & 85 & 42 & 89 & 6.0 & 14 & 56 & 58 \\
\hline
\end{tabular}

Following the bioleaching experiments performed in STB, mineralogical and microbiological analysis were performed on DT tailings (showing the best metal solubilization results), to better understand the mechanisms involved in the solubilization of the metals of interest. The comparison of the XRD patterns of the DT samples before and after bioleaching (Figure 5) reveals a notable decrease in pyrite content, confirming its oxidation through the bioleaching experiments. For RAT tailings, TESCAN analyzes on initial sample revealed that the tailings contain low levels of pyrite $(5.5 \%)$ and pyrrhotite $(0.22 \%)$ (Table 3$)$. These low levels are sufficient to support the growth of iron-oxidizing bacteria and the production of ferric iron acting as an oxidizing agent and promoting the solubilization of $U$, Th and REEs. These acidophilic sulfur-oxidizing bacteria, neutrophilic sulfur-oxidizing bacteria, and iron-oxidizing bacteria were enumerated by the most-probable number (MPN) technique of Cochran [17]. Initial wet samples of $1 \mathrm{~g}$ were placed in growth tubes and incubated in the dark at ambient temperature for a minimum of one month. For ironoxidizing bacteria, positive growth was indicated by the production of an obvious iron oxide precipitate in the tubes. For sulfur-oxidizing bacteria, positive growth was indicated by a decrease of growth medium $\mathrm{pH}$ (relative to uninoculated control tubes) of at least $0.5 \mathrm{pH}$ units following incubation, indicative of sulfuric acid production. Culture counts have shown a high concentration of iron oxidizers $\left(\geq 10^{6}\right.$ per gram) but a low concentration of sulfur oxidizers. These mineralogical (e.g., diminution of the pyrite content in bioleached sample relative to initial sample showed by the diminution of peak intensities of pyrite in XRD patterns) and microbiological (e.g., presence of iron-oxidizers and to a lesser extent of sulfur-oxidizer bacteria) results support the bioleaching of the pyrite and U-, Th- and REEs-bearing minerals by native iron oxidizing bacteria. 


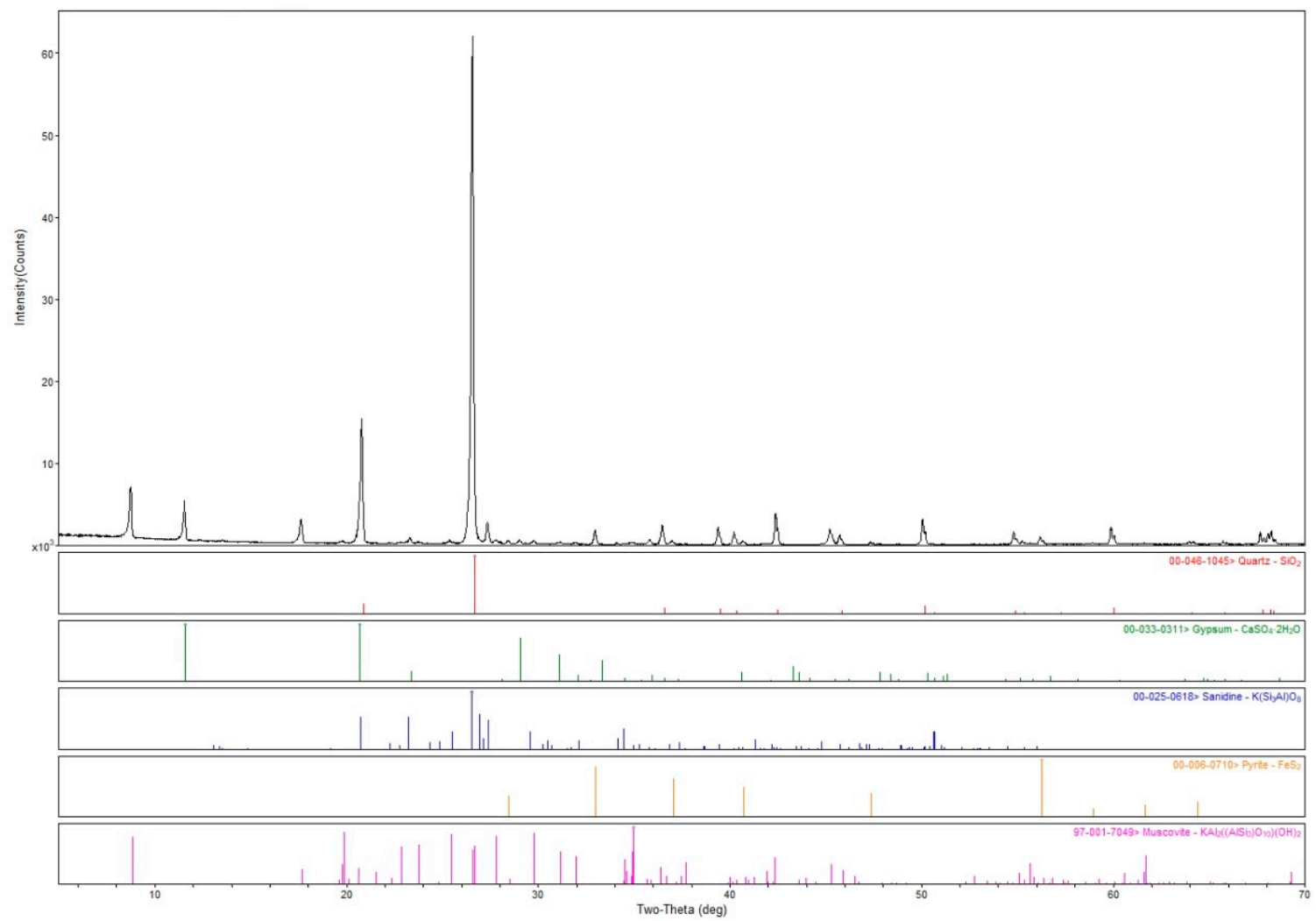

(a)

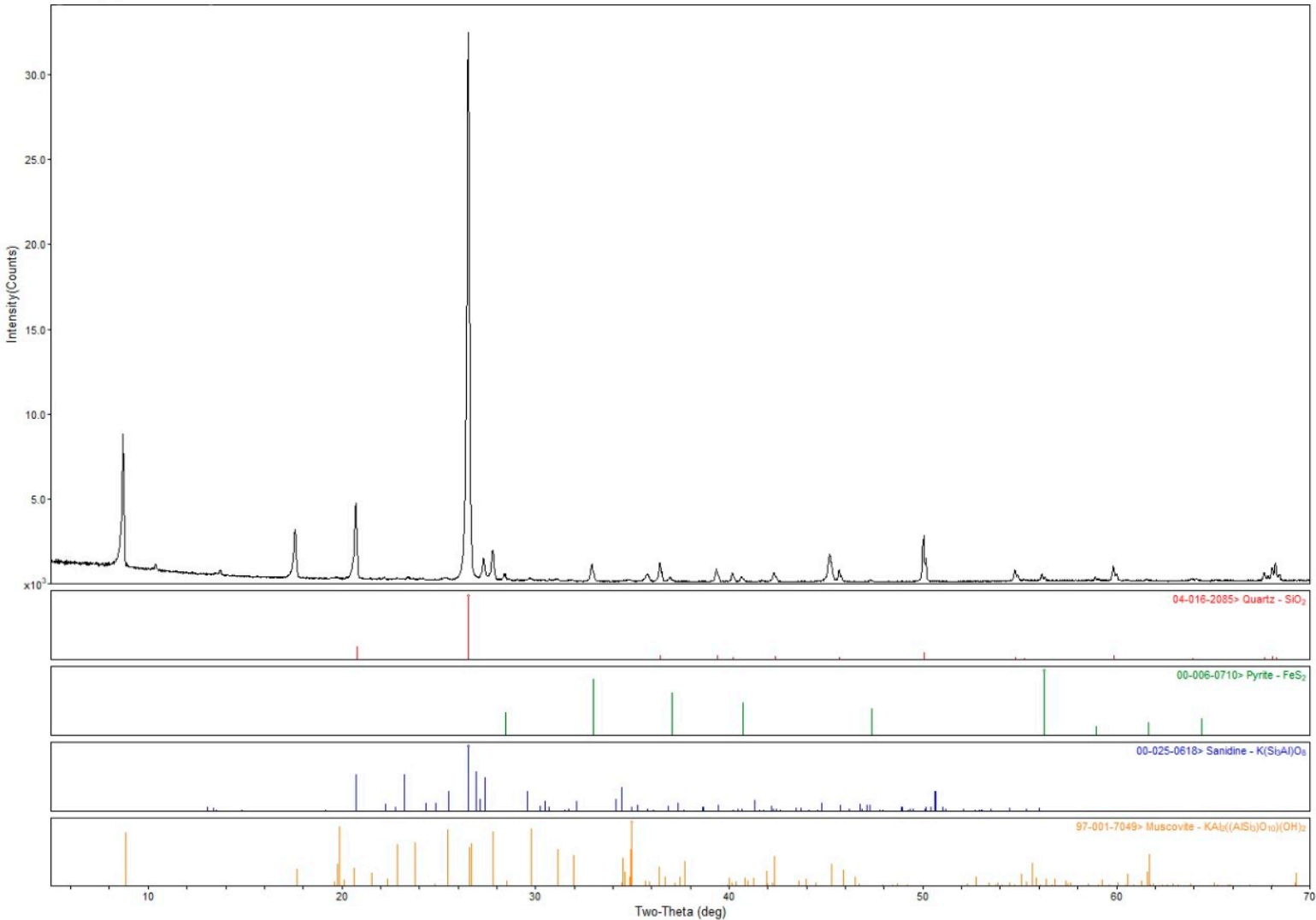

(b)

Figure 5. XRD patterns of DT before (a) and after (b) bioleaching obtained using a Rigaku D/MAX 2500 rotating anode powder diffractometer. 


\subsection{Selective Recovery of Lanthanides and Actinides from Bioleaching Solution Using Ion Exchange}

Table 8 presents the composition of the composite bioleaching solution subjected to ion exchange experiments. The concentrations of bioleached LREEs $(0.05-5.16 \mathrm{mg} / \mathrm{L})$ and HREEs $(0.03-0.77 \mathrm{mg} / \mathrm{L})$ were quite low compared to the concentrations of $\mathrm{U}(16.4 \mathrm{mg} / \mathrm{L})$ and $\mathrm{Th}(17.9 \mathrm{mg} / \mathrm{L})$. These results show the need to selectively preconcentrate the actinides from lanthanides using ion exchange resins to favor the recovery of these elements. Twenty ion exchange resins, including strong basic anionic (SBA), weak basic anionic (WBA), strong acid cationic (SAC), chelating and impregnated resins, have been tested to evaluate their efficiencies to selectively recover $U$, Th and REEs from the bioleaching solution (Table 9).

Table 8. Bioleaching solution composition.

\begin{tabular}{cc}
\hline Elements & Concentration (mg/L) \\
\hline $\mathrm{Fe}$ & 630 \\
\hline $\mathrm{Th}$ & 17.9 \\
$\mathrm{U}$ & 16.4 \\
\hline $\mathrm{Sc}$ & 0.04 \\
$\mathrm{Y}$ & 2.71 \\
$\mathrm{La}$ & 2.47 \\
$\mathrm{Ce}$ & 5.16 \\
$\mathrm{Pr}$ & 0.63 \\
$\mathrm{Nd}$ & 2.30 \\
$\mathrm{Sm}$ & 0.74 \\
$\mathrm{Eu}$ & 0.05 \\
$\mathrm{Gd}$ & 0.77 \\
$\mathrm{~Tb}$ & 0.13 \\
$\mathrm{Dy}$ & 0.74 \\
$\mathrm{Ho}$ & 0.12 \\
$\mathrm{Er}$ & 0.33 \\
$\mathrm{Tm}$ & 0.04 \\
$\mathrm{Yb}$ & 0.24 \\
$\mathrm{Lu}$ & 0.03 \\
\hline & \\
\hline & 0.34 \\
\hline & \\
\hline
\end{tabular}

From the screening results, it can be observed that Amberlite IRN77 and Lewatit SP112 resins, that are SAC, appear to be the most effective for REEs recovery. Indeed, Amberlite IRN77 sorbed $85 \%$ of the LREEs and $75 \%$ of the HREEs initially present in the bioleaching solution, while Lewatit SP112 sorbed $81 \%$ and $65 \%$ of the LREEs and HREEs, respectively. Despite the fact that a certain amount of Th (44-57\% of the initial quantity) is also adsorbed, a low amount of $U$ is sorbed on these SAC resins. This can be explained by the fact that the cationic exchangers tend to adsorb elements according to the positive charge of the metal to be eliminated, following the trend: $\mathrm{M}^{4+}>\mathrm{M}^{3+}>\mathrm{M}^{2+}>\mathrm{M}^{+}>\mathrm{Na}^{+}>\mathrm{H}^{+}$. As Th and REEs are predominantly charged $4+$ and $3+$, respectively, they should be preferentially sorbed towards uranyl ions $\left(\mathrm{UO}_{2}{ }^{2+}\right)$. To see if this resin can be used on a larger scale, desorption tests should be carried out and the percentage of REEs recovered during elution should be determined. The concentration factor of these elements should also be evaluated.

Lewatit MP500 and Reillex 425 resins, that are strong and weak anionic resins, respectively, seem to have very good affinity for U (93-97\%) and low affinity for REEs (1-4\%). In general, cationic resins seem more effective for the extraction of $U$, which is expected to be present as uranyl ion $\left(\mathrm{UO}_{2}{ }^{2+}\right)$, under the $\mathrm{pH}$ and the ORP conditions measured in the bioleaching solution ( 2 and $550 \mathrm{mV}$, respectively). However, this oxidized form of $\mathrm{U}$ can form negative complexes by binding to carbonate $\left(\mathrm{CO}_{3}{ }^{2-}\right)$ and sulfate $\left(\mathrm{SO}_{4}{ }^{2-}\right)$ ions also present in the bioleaching solution. Therefore, it may be possible to selectively recover $\mathrm{U}$ from the bioleaching solution beforehand with this anionic resin, coupled with a second resin to recover REEs. 
Table 9. Screening results for the extraction (\%) of Sc, Fe, Th, U, LREEs, and HREEs.

\begin{tabular}{|c|c|c|c|c|c|c|c|c|}
\hline Name & Resin Type & Functional Group & Sc $(\%)$ & $\mathrm{Fe}(\%)$ & Th (\%) & $\mathrm{U}(\%)$ & LREEs (\%) & HREEs (\%) \\
\hline Dowex 21K-XLT & SBA & Quaternary amine & 0 & 0 & 14 & 77 & 3 & 3 \\
\hline Lewatit MP500 & SBA & Quaternary amine & 4 & 0 & 14 & 93 & 1 & 1 \\
\hline Purolite A500 & SBA & Quaternary amine & 28 & 0 & 7 & 85 & 3 & 4 \\
\hline Reillex 425 & WBA & Poly-4-vinylpyridine & 13 & 0 & 52 & 97 & 4 & 3 \\
\hline Reillex HPQ & SBA & Quaternary amine & 0 & 0 & 14 & 80 & 4 & 3 \\
\hline Lewatit A365 & WBA & Polyamine & 18 & 0 & 28 & 74 & 3 & 3 \\
\hline Amberlite IR120 & SAC & Sulfonic & 15 & 9 & 20 & 5 & 61 & 48 \\
\hline Lewatit SP112 & SAC & Sulfonic & 0 & 12 & 57 & 3 & 81 & 65 \\
\hline Amberlite IRN77 & SAC & Sulfonic & 13 & 26 & 44 & 6 & 85 & 75 \\
\hline Rhom \& Haas GT73 & Chelating & Thiol & 0 & 1 & 26 & 14 & 63 & 38 \\
\hline Lewatit TP214 & Chelating & Thiourea & 13 & 0 & 11 & 31 & 3 & 3 \\
\hline Dowex M4195 & Chelating & Bis-picolylamine & 2 & 2 & 15 & 84 & 7 & 5 \\
\hline Lewatit TP260 & Chelating & Amino methyl phosphonic & 69 & 28 & 55 & 93 & 30 & 30 \\
\hline Lewatit TP207 & Chelating & Iminodiacetate & 0 & 22 & 23 & 24 & 4 & 4 \\
\hline Diphonix & Analytical & Diphosphonic and sulfonic & 55 & 44 & 56 & 42 & 20 & 19 \\
\hline UTEVA & Analytical & Diamyl, amylphosphonate & 0 & 0 & 5 & 0 & 3 & 3 \\
\hline Lewatit VPOC 026 & Impregnated & D2EHPA & 65 & 21 & 69 & 71 & 4 & 25 \\
\hline Lewatit TP272 & Impregnated & Trimethylpentyl-phosphinic & 94 & 13 & 11 & 99 & 4 & 4 \\
\hline
\end{tabular}


Lewatit VPOC1026 and TP272 resins, that are impregnated resins, are very efficient for actinides (69-99\%) and Sc recovery (65-94\%), but eluting these resins can be difficult as it requires the use of alkaline solutions that may desorb the impregnated ligand. Desorption tests would therefore be necessary to verify the potential use of these resins for the selective recovery of Sc and actinides. Being primarily in its tetravalent form, Th(IV) has no affinity for the different resins tested and is only weakly adsorbed on most of the tested resins, with the highest recoveries observed with impregnated resins (e.g., Diphonix, Lewatit VPOC1026).

Additional experiments were conducted to evaluate the capacity for the six resins selected according to the screening step (Figures 6-8). The adsorption of REEs on the SAC resins Amberlite IRN77 and Lewatit SP112 was evaluated using different masses of resins (Figure 6). The results show that the recovery of LREEs and Th reached $80 \%$ when using only 1-2 g of resins to treat $100 \mathrm{~mL}$ of bioleaching solution. However, HREEs recovery and Fe co-extraction was slightly lower when using the SP112 resin relative to Amberlite IRN77. The Lewatit SP112 seems to be more efficient for the selective recovery of Th and REEs from the bioleaching solution, while minimizing the adsorption of $U$.

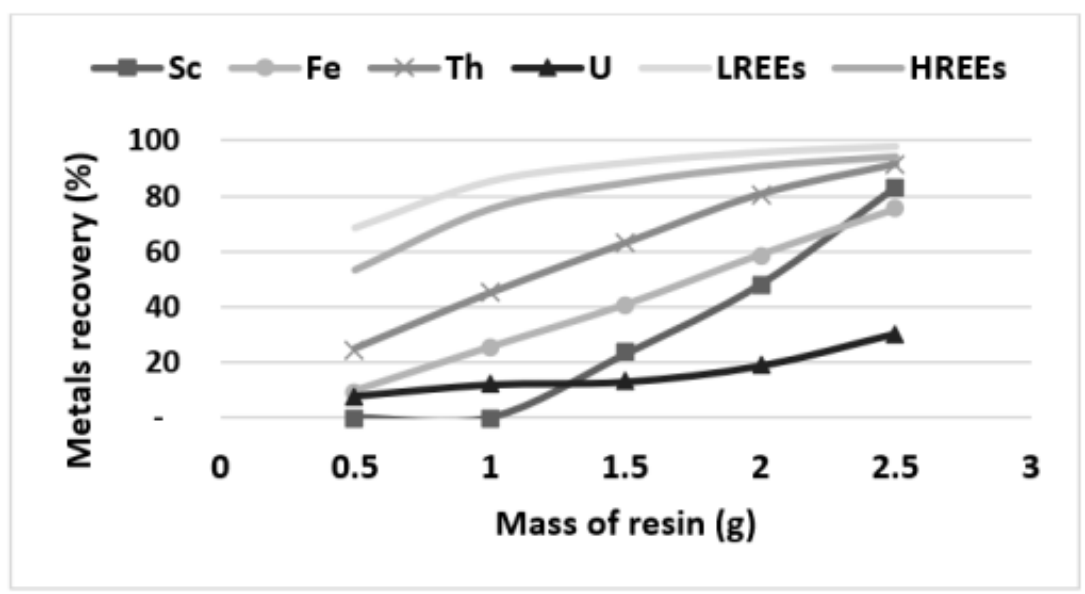

(a)

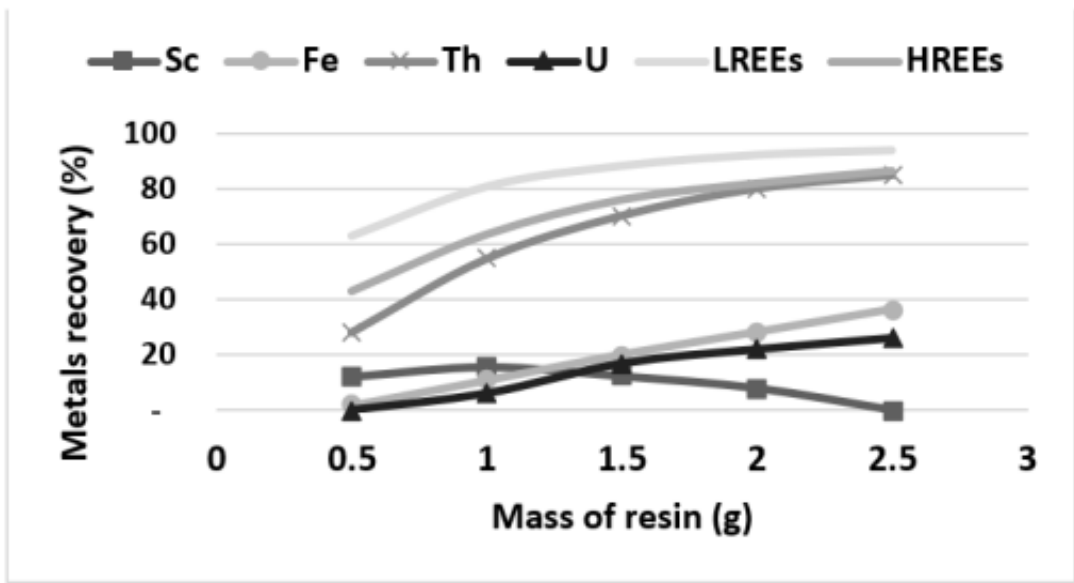

(b)

Figure 6. Amberlite IRN77 (a) and Lewatit SP112 (b) resins capacity evaluation with $100 \mathrm{~mL}$ of bioleaching solution.

The Lewatit MP500 allows very selective recovery of $U$, while the Reillex 425 co-extract both actinides (U and $\mathrm{Th}$ ) from the solution (Figure 7). It can be noticed that only $0.5 \mathrm{~g}$ of Lewatit MP500 were required to extract more than $90 \%$ of U from bioleachate, while the co-extraction of $U(99 \%)$ and Th $(80 \%)$ by the Reillex 425 required a higher amount (2 
g) of resin. Based on purchasing costs of these resins at laboratory scale (Lewatit MP500: $500 \$$ for $15 \mathrm{~kg}$ and Reillex 425: $1000 \mathrm{CA} \$$ for $1 \mathrm{~kg}$ ), it is expected that the use of Lewatit MP500 will be more promising in terms of operating costs (e.g., lower amounts required and purchasing costs) relative to Reillex 425 . Moreover, it can be noticed that very low amounts of both LREEs and HREEs were adsorbed on the selected resins, indicating that the low losses $(<10 \%)$ of these elements will be achieved, while recovering $U$ and Th. Based on these results, it is expected that Lewatit MP500 will be efficient for $\mathrm{U}$ and Th recovery and more economically than Reillex 425. However, additional experiments related to the elution and regeneration of these resins are required to confirm this statement.

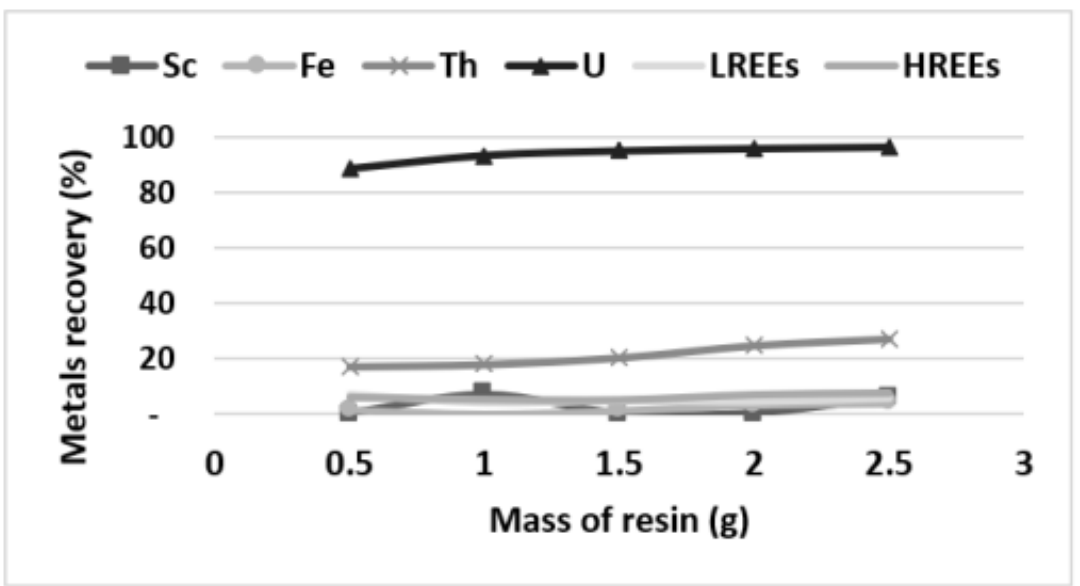

(a)

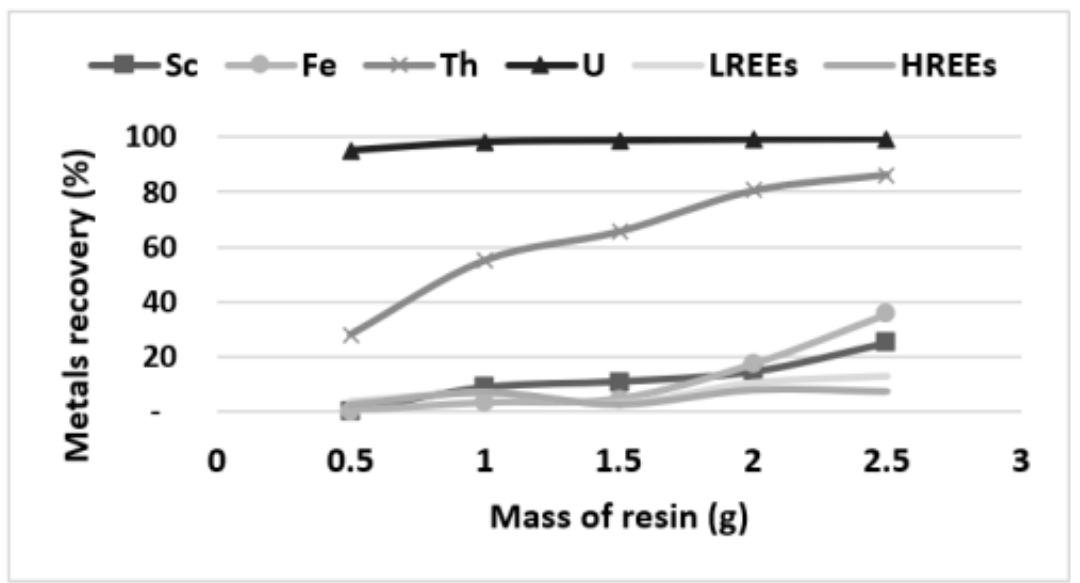

(b)

Figure 7. Lewatit MP500 (a) and Reillex 425 (b) resins capacity evaluation with $100 \mathrm{~mL}$ of bioleaching solution.

Figure 8 shows an efficient co-extraction of Sc and U by the Lewatit VPOC 1026 and TP272 resins. Using one gram of resin, the Lewatit TP272 is more efficient for U extraction $(99 \%)$ and is more selective ( $<10 \%$ of REEs and Th sorbed) than the VPOC 1026 resin $(80 \%$ of $\mathrm{U}, 50 \%$ of Th and $20 \%$ of REEs sorbed). Desorption tests will be necessary to verify the potential use of this resin for the selective recovery of Sc and U.

Based on these results, the use of Lewatit TP272 resin for the selective recovery of Sc and U followed by the Lewatit SP112 resin for the recovery of Th and REEs seems a promising method for the co-extraction of key elements from the bioleaching solution. 


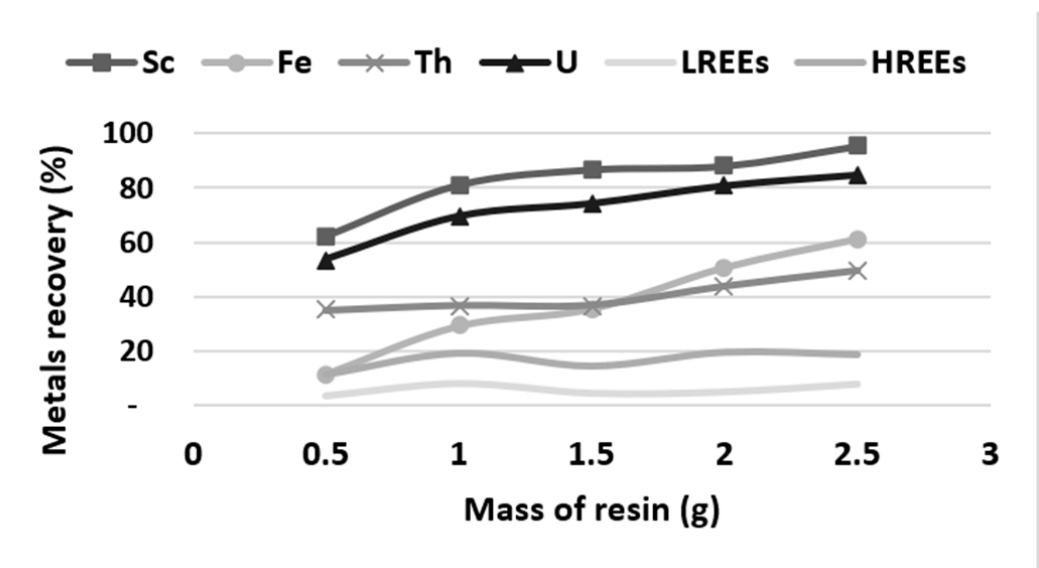

(a)

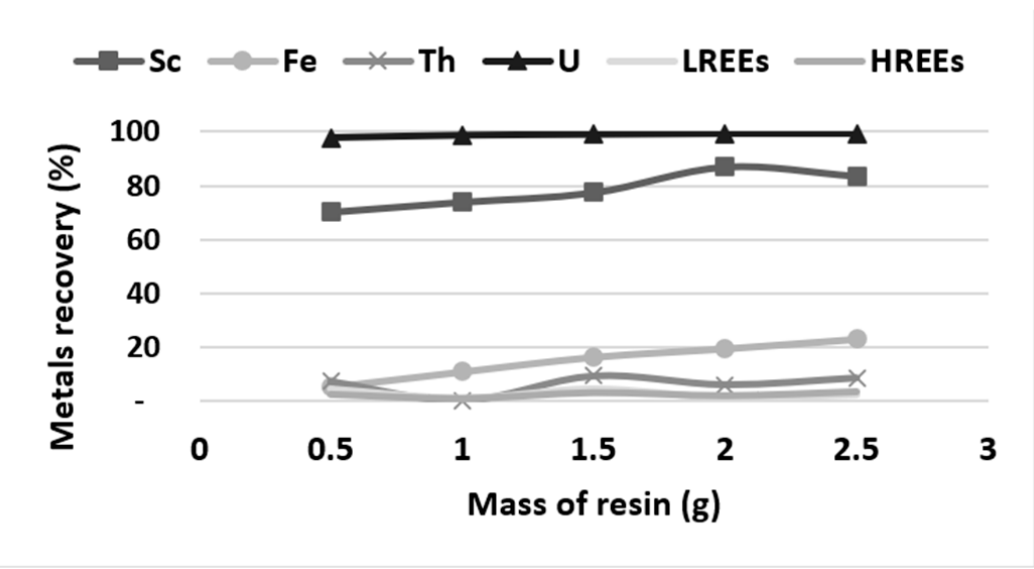

(b)

Figure 8. Lewatit VPOC1026 (a) and TP272 (b) resins capacity evaluation with $100 \mathrm{~mL}$ of bioleaching solution.

\section{Conclusions}

The present study aimed to evaluate the potential to use native sulfur- and ironoxidizing bacteria for the bioleaching of REEs, Th and U from uranium mine tailings collected from two decommissioned mines (named DT and RAT). Tailings were characterized and subjected to sequential extraction to better understand the partitioning of the elements of interest (e.g., $\mathrm{U}, \mathrm{Th}$ and REEs). Bioleaching experiments were performed using shake flasks (to identify the optimal operating conditions in terms of temperature) and then, stirred tank bioreactors (to better represent the systems used at commercial scale). Preliminary ion exchange experiments were conducted to evaluate the potential to selectively recover the actinides and lanthanides from the bioleaching solutions.

Collected mine tailings initially contained Th $(146-204 \mathrm{mg} / \mathrm{kg}), \mathrm{U}(67.1-378 \mathrm{mg} / \mathrm{kg})$ and REEs (1330-1760 mg/kg), with LREEs accounting for $85-97 \%$ of the TREEs. Sequential extraction showed that $\mathrm{U}$ from RAT was mainly associated to the weak acid soluble fraction. Therefore, this element was expected to dissolve easily from these tailings. Iron and LREEs seems to be mainly present in the residual fraction, while Th and HREEs were split between the weak acid, the Fe-Mn oxide, and the residual fractions. Therefore, it was expected to get a better bioleaching of HREEs associated with Fe- and S-minerals (pyrite) relative to LREEs mainly associated to more refractory minerals encountered in the residual fraction.

Bioleaching experiments in batch mode showed high solubilization of $U(87 \%)$, while Th and HREEs solubilization remained low $(<30 \%)$ for RAT tailings. For the DT tailings, the solubilization of the elements of interest was slower, but high solubilization yields were observed for both Th $(>76 \%)$ and HREEs $(>56 \%)$. However, the solubilization of $\mathrm{U}$ 
was moderate (42\%). The higher solubilization of Th and HREEs observed for DT tailings might be due to the smallest particle size as well as the higher proportion of both Th and HREEs associated to the Fe-Mn oxides and the lower proportion associated to the residual fraction in DT tailings compared to RAT tailings. In stirred tank bioreactors, the extraction efficiencies of Th and REEs (especially HREEs) were higher than the ones obtained on a smaller scale, that can be explained by a better control of operating conditions (e.g., mixing speed and aeration rate). Following the stirred tank bioreactor experiments, XRD analysis of the final sample and the culture counts supported the bioleaching of the pyrite and REEs-bearing minerals by iron oxidizing bacteria.

Screening of ion exchange resins has allowed the identification of two resins for the selective recovery of REEs, Sc, $\mathrm{U}$ and Th from the bioleaching solution. The use of Lewatit TP272 resin for the recovery of Sc and U followed by the Lewatit SP112 resin for the recovery of Th and REEs seemed to be a promising method for the co-extraction of the key elements.

Bioleaching processes are very economic due to the low demand of chemical reagents. Ion exchange separation is also economic and solutions may be recycled. An economic analysis will be developed and a scale-up of the developed process will be investigated to enhance the production of REEs, $\mathrm{U}$ and Th from uranium tailings, to maximize the exploitation of mineral resources while mitigating environmental impacts related to longterm management of solid waste.

Supplementary Materials: The following are available online at https:/ / www.mdpi.com/2075-1 63X/11/3/302/s1, Figure S1: Evolution of LREEs (a), HREEs (b), U (c) and Th (d) removal yields for RAT tailings, Figure S2: Evolution of LREEs (a), HREEs (b), U (c) and Th (d) removal yields for DT tailings.

Author Contributions: Conceptualization, N.R., J.-F.B., L.C. and R.C.; methodology, N.R., R.G.T.; validation, N.R., R.G.-T., J.-F.B. and L.C.; investigation, N.R., R.G.-T.; writing-original draft preparation, N.R., R.G.-T.; writing-review and editing, N.R., J.-F.B., L.C., S.C. and R.C. All authors have read and agreed to the published version of the manuscript.

Funding: The authors acknowledge the funding from FRQNT (Fonds de Recherche du QuébecNature et Technologies; Québec's Research Funds-Nature and Technology, grant 2017-MI-202293), Canada Research Chairs Program (950-232194). This work was supported by CanmetMINING's Rare Earth Elements program.

Institutional Review Board Statement: Not applicable.

Informed Consent Statement: Not applicable.

Data Availability Statement: Not applicable.

Acknowledgments: The authors would like to thank Derek Smith and Yves Thibault for the mineralogical characterization; Ted Mackinnon and Sean Langley for the microbiological characterization, and Cheryl Laviolette for the chemical analyses. The authors thank the two internal reviewers (Bryan Tisch and Mehdi Mostajeran) from CANMET and the four anonymous reviewers who provided very constructive comments and greatly contributed to the improvement of this manuscript.

Conflicts of Interest: The authors declare no conflict of interest.

\section{References}

1. Brandl, H.; Barmettler, F.; Castelberg, C.; Fabbri, C. Microbial mobilization of rare earth elements (REE) from mineral solids: A mini review. AIMS Microbiol. 2016, 3, 190-204. [CrossRef]

2. Rasoulnia, P.; Barthen, R.; Lakaniemi, A.M. A critical review of bioleaching of rare earth elements: The mechanisms and effect of process parameters. Crit. Environ. Sci. Tech. 2020. [CrossRef]

3. Hopfe, S.; Konsulke, S.; Barthen, R.; Lehmann, F.; Kutschke, S.; Pollmann, K. Screening and selection of technologically applicable microorganisms for recovery of rare earth elements from fluorescent powder. Waste Manag. 2018, 79, 554-563. [CrossRef] [PubMed]

4. Fathollahzadeh, H.; Eksteen, J.J.; Kaksonen, A.H.; Watkin, E.L.J. Role of microorganisms in bioleaching of rare earth elements from primary and secondary resources. Appl. Microbiol. Biotechnol. 2019, 103, 1043-1057. [CrossRef] [PubMed] 
5. Kaksonen, A.H.; Lakaniemi, A.M.; Tuovinen, O.H. Acid and ferric sulfate bioleaching of uranium ores: A review. J. Cleaner Prod. 2020, 121586. [CrossRef]

6. Whitty-Léveillée, L. Nouvelles Approches pour la Séparation des Actinides dans les Gisements de Terres Rares. Ph.D. Thesis, Laval University, Québec City, QC, Canada, 2019.

7. Costis, S.; Mueller, K.K.; Coudert, L.; Neculita, C.M.; Reynier, N.; Blais, J.F. Recovery potential of rare earth elements from mining and industrial residues: A review and cases studies. J. Geochem. Explor. 2021, 221, 106699. [CrossRef]

8. Munoz, J.A.; Gonzalez, F.; Blazquez, M.L.; Ballester, A. A Study of the bioleaching of a Spanish uranium ore. Part II: Orbital shaker experiments. Hydrometallurgy 1995, 38, 79-97. [CrossRef]

9. Nerkar, D.P.; Lewis, N.F.; Kumta, U.S. Solubilization of uranium from low grade ores by bacteria. In Proceedings of the Symposium on Biological Approach to Problems in Medicine, Industry and Agriculture, Bombay, India, 12-14 March 1974.

10. Choi, M.S.; Cho, K.S.; Kim, D.S.; Ryu, H.W. Bioleaching of uranium from low grade black schists by Acidithiobacillus ferrooxidans. World J. Microbiol. Biotechnol. 2005, 21, 377-380. [CrossRef]

11. Tessier, A.; Campbell, P.G.C.; Bisson, M. Sequential extraction procedure for the speciation of particulate trace metals. Anal. Chem. 1979, 51, 844-851. [CrossRef]

12. McCready, R.G.L.; Wadden, D.; Marchbank, A. Nutrient requirements for the in-place leaching of uranium by Thiobacillus ferrooxidans. Hydrometallurgy 1986, 17, 61-71. [CrossRef]

13. Abaka-Wood, G.B.; Addai-Mensah, J.; Skinner, W. Characterisation of Mining Tailings for the Beneficiation of Rare Earth Elements Minerals. In Proceedings of the UMaT Biennial International Mining and Mineral Conference, Tarkwa, Ghana, 4-7 August 2020.

14. Lottermoser, B.G.; Ashley, P.M. Tailings dam seepage at the rehabilited Mary Kathleen uranium mine, Australia. J. Geochem. Explor. 2005, 85, 119-137. [CrossRef]

15. Anju, M.; Banerjee, D.K. Comparison of two sequential extraction procedures for heavy metal partitioning in mine tailings. Chemosphere 2010, 78, 1393-1402. [CrossRef]

16. Fathollahzadeh, H.; Khaleque, H.N.; Eksteen, J.; Kaksonen, A.H.; Watkin, E.L.J. Effect of glycine on bioleaching of rare earth elements from Western Australian monazite by heterotrophic and autotrophic microorganisms. Hydrometallurgy 2019, 189, 105-137. [CrossRef]

17. Cochran, W.G. Estimation of bacterial densities by means of the most probable number. Biometrics 1950, 6, 105-116. [CrossRef] [PubMed] 